\title{
Nuclear upregulation of PI3K p110 correlates with increased rRNA transcription in endometrial cancer cells
}

Fatemeh Mazloumi Gavgani ${ }^{1^{* \dagger}}$, Thomas Karlsson ${ }^{1 *}$, Ingvild L Tangen ${ }^{2,3}$, Andrea Papdiné Morovicz $^{1}$, Victoria Smith Arnesen ${ }^{1 \ddagger}$, Diana C. Turcu ${ }^{1}$, Camilla Krakstad ${ }^{2,3}$, Julie GuillermetGuibert $^{4}$, and Aurélia E Lewis ${ }^{1 \S}$

${ }^{1}$ Department of Biological Sciences, University of Bergen, Norway.

${ }^{2}$ Centre for Cancer Biomarkers, Department of Clinical Science, University of Bergen, Norway.

${ }^{3}$ Department of Gynaecology and Obstetrics, Haukeland University Hospital, Bergen, Norway.

${ }^{4}$ Centre de Recherches en Cancérologie de Toulouse (CRCT), Institut National de la Santé et de la Recherche Médicale (INSERM), Université Toulouse III Paul Sabatier, Toulouse, France.

* equal authorship

§ Corresponding author: Aurélia E. Lewis, Department of Biological Sciences, University of Bergen, PO Box 7803, N-5020 Bergen, Norway. Email: aurelia.lewis@uib.no.

$\dagger$ present address: The Sars International Centre for Marine Molecular Biology, Bergen 5006, Norway.

‡ present address: Department of Biomedicine, University of Bergen 


\begin{abstract}
Genes encoding for components of the phosphoinositide 3-kinase (PI3K) pathway are frequently mutated in cancer, including inactivating mutations of PTEN and activating mutations of PIK3CA, encoding the PI3K catalytic subunit $\mathrm{p} 110 \alpha$. PIK3CB, encoding $\mathrm{p} 110 \beta$, is rarely mutated, but can contribute to tumourigenesis in some PTEN-deficient tumours. The underlying molecular mechanisms are however poorly understood. By analysing cell lines and annotated clinical samples, we have previously found that $\mathrm{p} 110 \beta$ is highly expressed in endometrial cancer (EC) cell lines and that PIK3CB mRNA levels increase early in primary tumours correlating with lower survival. Selective inhibition of p110 $\alpha$ and p110 $\beta$ led to different effects on cell signalling and cell function, p110 $\alpha$ activity being correlated to cell survival in PIK3CA mutant cells and p110 $\beta$ with cell proliferation in PTEN-deficient cells. To understand the mechanisms governing the differential roles of these isoforms, we assessed their sub-cellular localisation. $\mathrm{p} 110 \alpha$ was cytoplasmic whereas $\mathrm{p} 110 \beta$ was both cytoplasmic and nuclear with increased levels in both compartments in cancer cells. Immunohistochemistry of $\mathrm{p} 110 \beta$ in clinically annotated patient tumour sections revealed high nuclear/cytoplasmic staining ratio, which correlated significantly with higher grades. Consistently, the presence of high levels of $\mathrm{p} 110 \beta$ in the nuclei of EC cells, correlated with high levels of its product phosphatidylinositol 3,4,5-trisphosphate $\left(\operatorname{PtdIns}(3,4,5) P_{3}\right)$ in the nucleus. Using immunofluorescence labelling, we observed both $\mathrm{p} 110 \beta$ and $\operatorname{PtdIns}(3,4,5) P_{3}$ in the nucleoli of EC cell lines. The production of nucleolar PtdIns(3,4,5) $P_{3}$ was dependent upon p110 $\beta$ activity. EC cells with high levels of nuclear PtdIns(3,4,5) $P_{3}$ and $\mathrm{p} 110 \beta$ showed elevated nucleolar activity as assessed by the increase in $47 \mathrm{~S}$ pre-rRNA transcriptional levels in a p110 $\beta$ dependent manner. Altogether, these results present a nucleolar role for the PI3K pathway that may contribute to tumour progression in endometrial cancer.
\end{abstract}




\section{Introduction}

The phosphatidylinositol 3-kinase (PI3K) signalling pathway is frequently hyperactivated in cancer, often due to genetic or epigenetic alterations in several gene members of the pathway [1-3]. Class I PI3Ks consist of heterodimers of catalytic subunits (p110 $\alpha, \beta, \delta$ or $\gamma$ ) and adaptor proteins (p85 $\alpha$ and its variants, $p 85 \beta$ or p55 $\gamma$ ) [4] and phosphorylate the 3'hydroxyl group of the phospholipid phosphatidylinositol 4,5-bisphosphate (PtdIns $\left.(4,5) P_{2}\right)$ to generate phosphatidylinositol 3,4,5-trisphosphate (PtdIns(3,4,5) $\left.P_{3}\right)$. PtdIns(3,4,5) $P_{3}$ binds to effector proteins including the serine/threonine kinases AKT/Protein Kinase B (PKB), 3phosphoinositide-dependent protein kinase 1 (PDK1) and SIN1 via their phosphoinositidebinding plextrin homology (PH) domain [5]. AKT is activated by phosphorylation on Thr308 and Ser473 by PDK1 and mammalian target of rapamycin complex 2 (mTORC2) respectively [6]. Activated AKT can act at different intracellular sites, where it phosphorylates a myriad of substrates that regulate cell survival, cell proliferation and growth as well as metabolism [7]. The production of PtdIns(3,4,5) $P_{3}$ is regulated by phosphatase and tensin homolog deleted on chromosome 10 (PTEN), a lipid phosphatase which dephosphorylates PtdIns(3,4,5) $P_{3}$ back to PtdIns(4,5) $P_{2}$, thereby opposing PI3K-mediated signalling and hence limiting the potential cancer-promoting effects of class I PI3K activity [8].

p110 $\alpha$ and p110 $\beta$ are ubiquitously expressed, share the same enzymatic properties, generate the same lipid product, and initiate the same signalling cascade. Despite these shared features, the two isoforms are both essential in combination for development as individual knockout mice are embryonically lethal, hence suggesting non-redundant functions $[9,10]$. Moreover, their mode of activation can be distinct, with p110 $\alpha$ carrying out most of receptor tyrosine kinase (RTK)-mediated PI3K signalling and p110 $\beta$ by G-protein coupled receptors (GPCR) as well as RTKs [3, 11-13] through different adaptor proteins [14]. In cancer, the oncogenic properties of $\mathrm{p} 110 \alpha$ are due to activating mutations of its gene PIK3CA [15]. In contrast, $P I K 3 C B$, the gene encoding $\mathrm{p} 110 \beta$, is rarely mutated in cancer, with only three reports so far describing activating mutations [16-18]. PIK3CB was however shown to be the key isoform mediating tumour growth in PTEN-deficient tumours in particular in breast, prostate and ovarian cancer cells [13, 19-22], possibly due to its ability to promote oncogenic transformation in its wild type state [23]. Furthermore, the importance of p110 $\beta$ in tumourigenesis was recently highlighted in a study by Juric et al [24]. This study showed that PIK3CA mutant breast cancer cells, which were initially sensitive to $\mathrm{p} 110 \alpha$ specific inhibition, eventually developed resistance with acquired loss of PTEN in metastatic lesions. These cells 
could however reverse the resistance when p110 $\beta$ inhibition was combined. Regarding their functions, a few studies have reported that the two isoforms can contribute differently to cell survival and proliferation, with p110 $\alpha$ playing more of a role in cell survival and p110 $\beta$ in cell cycle progression and DNA replication [25-27]. Another distinguishing feature about these two isoforms is their sub-cellular localisation. Although $\mathrm{p} 110 \alpha$ and $\beta$ are both found in the cytoplasm and share/compete for similar upstream receptor activation and downstream signalling cascades, p110 $\beta$ harbours a nuclear localisation signal and is found in the nucleoplasm, the chromatin fraction $[27,28]$ as well as in the nucleolus together with its product PtdIns(3,4,5) $P_{3}$ [29]. This would suggest that p110 $\beta$ can orchestrate different processes emanating from the nucleus and explain, at least partly, the pleiotropic aspects of the PI3K pathway.

The PI3K pathway is the signalling pathway most frequently altered in endometrial cancer (EC) with more than $80 \%$ of tumours harbouring somatic alteration in at least one gene component of the pathway [30]. This includes high frequency mutations in PTEN, PIK3CA and PIK3R1 (encoding p85 $\alpha$ ) and low frequency in Akt and PIK3R2 (encoding p85 $\beta$ ) [31, 32]. Loss of function of the tumour suppressor gene PTEN, due to loss of heterozygosity or somatic mutations is the most common event in type I endometrioid EC (EEC) and occurs early in 18$48 \%$ of lesions with atypical hyperplasia [33, 34]. PIK3CA is the second most frequently mutated in EC with mutations occurring in type I EEC and type II non endometrioid EC serous lesions [32, 34-40]. In addition, mutations in PTEN were found to co-exist with those of PIK3CA or PIK3R1, thereby leading to enhanced activation of the PI3K pathway [35, 39, 41, 42]. PIK3CA gene amplification can also account for other mechanisms for PI3K pathway activation and tend to segregate more frequently to aggressive and invasive type II tumours [37, 39, 40, 43]. In contrast to PIK3CA, mutation events are rare in PIK3CB and account for 2 to 10 $\%$ in EC according to public data from the Catalog of Somatic Mutations In Cancer (COSMIC, v90) or The Cancer Genome Atlas [37, 40, 44]. In particular, two oncogenic mutations located in its catalytic domain have recently been characterized [17, 45]. PIK3CB mRNA levels were found to be elevated in endometrial tumours compared to normal tissue in a few patient samples [46]. In a recent study, we have shown that the p110 $\beta$ protein levels are elevated in EC cell lines and that mRNA levels are increased in grade 1 endometrioid endometrial lesions compared to complex hyperplasias [47]. We have recently reported the presence of $\mathrm{p} 110 \beta$ and of its product PtdIns(3,4,5)P $P_{3}$ in the nucleolus of the breast cancer cell line AU565 [29]. In this study, we showed an increase in the nuclear levels of both $\mathrm{p} 110 \beta$ and $\operatorname{Ptd} \operatorname{Ins}(3,4,5) P_{3}$ in EC cells. We further showed that high p1 $10 \beta$ levels correlated with high rRNA transcription, which 
was partly dependent on $\mathrm{p} 110 \beta$ activity. These results suggest therefore the involvement of this kinase and its lipid product PtdIns(3,4,5) $P_{3}$ in increased nucleolar activity in cancer.

\section{Results}

\section{p110 $\beta$ is cytoplasmic and nuclear in endometrial cancer cell lines and patient tumours}

Previous studies have shown that $\mathrm{p} 110 \alpha$ and $\mathrm{p} 110 \beta$ are differently localized and that this may contribute to their different cellular function [27-29]. Using cell fractionation and Western immunoblotting, we determined the subcellular localization of PI3K catalytic isoforms, as well as the two regulatory subunits p85 $\alpha$ and p85 $\beta$, in EC cells compared to a non-tumour immortalized endometrial cell line (EM). As shown in Figure 1A, p110 $\alpha$ concentrated to the cytoplasmic fraction in all cell lines. p110 $\beta$ expression was low in EM cells detected mostly in the cytoplasmic fraction and with very low levels in nuclear fractions. All cancer cell lines had higher levels of $\mathrm{p} 110 \beta$ in the cytoplasmic fraction than EM cells. In the nuclear fractions, all cancer cell lines demonstrated high p110 $\beta$ levels except for EFE-184 cells. In the majority of cell lines, p85 $\alpha$ was restricted to the cytoplasmic fraction. In contrast, p85 $\beta$ was mostly undetectable in the cytoplasmic fraction in all cells except for MFE-280 cells, but was concentrated to the nuclear fraction, with high levels in EM, KLE, EFE-184 and MFE-280 cells and lower levels in the remaining cells (Figure 1A). To determine if the expression and localization pattern of p110 $\beta$ could also be observed in human tissues, we examined a patient cohort of 727 primary endometrial tumours by immunohistochemistry of tissue microarray (TMA). The level and intensity patterns of p1 $10 \beta$ were scored separately in the cytoplasm and nucleus. While most patients showed p110 $\beta$ cytoplasmic detection with various degrees of intensity, 23\% of all cases showed nuclear staining (Figure 1B). In addition, a significant correlation was observed between high nuclear to cytoplasmic score ratio for p110 $\beta$ and high grade or histological type II (non-endometrioid) endometrial tumour (Figure 1C).

\section{Figure 1 legend: $\mathbf{p} 110 \beta$ localises to the nucleus in endometrial cancer cells}

(A) Actively growing cells were fractionated into cytoplasmic and nuclear fractions. Equal protein concentrations were resolved by SDS-PAGE and analysed by Western immunoblotting using the antibodies as indicated. (B) Representative histochemistry images of cytoplasmic and nuclear $\mathrm{p} 110 \beta$ staining in primary endometrial tumours detected with anti-p110 $\beta$. Magnification x20. (C) Quantitative graphs of nuclear (N) to cytoplasmic (C) ratio measured 
bioRxiv preprint doi: https://doi.org/10.1101/2019.12.20.884122; this version posted December 20, 2019. The copyright holder for this preprint (which was not certified by peer review) is the author/funder. All rights reserved. No reuse allowed without permission.

Figure 1

A
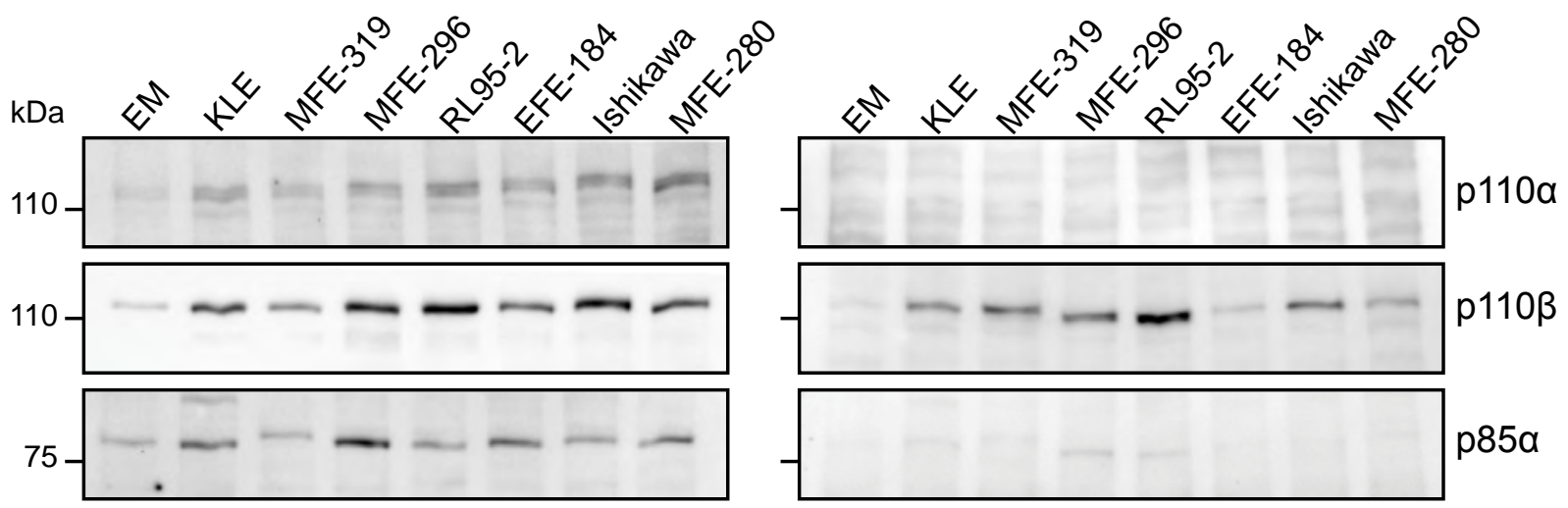

p85a
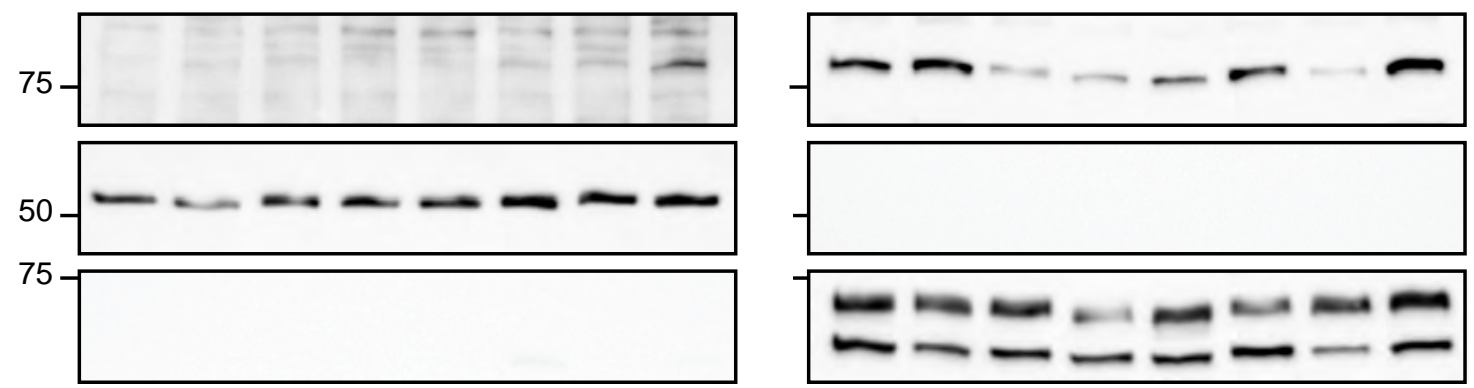

Cytoplasm

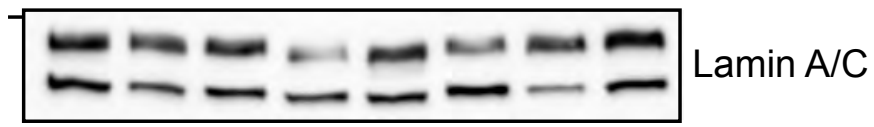

Nucleus

B
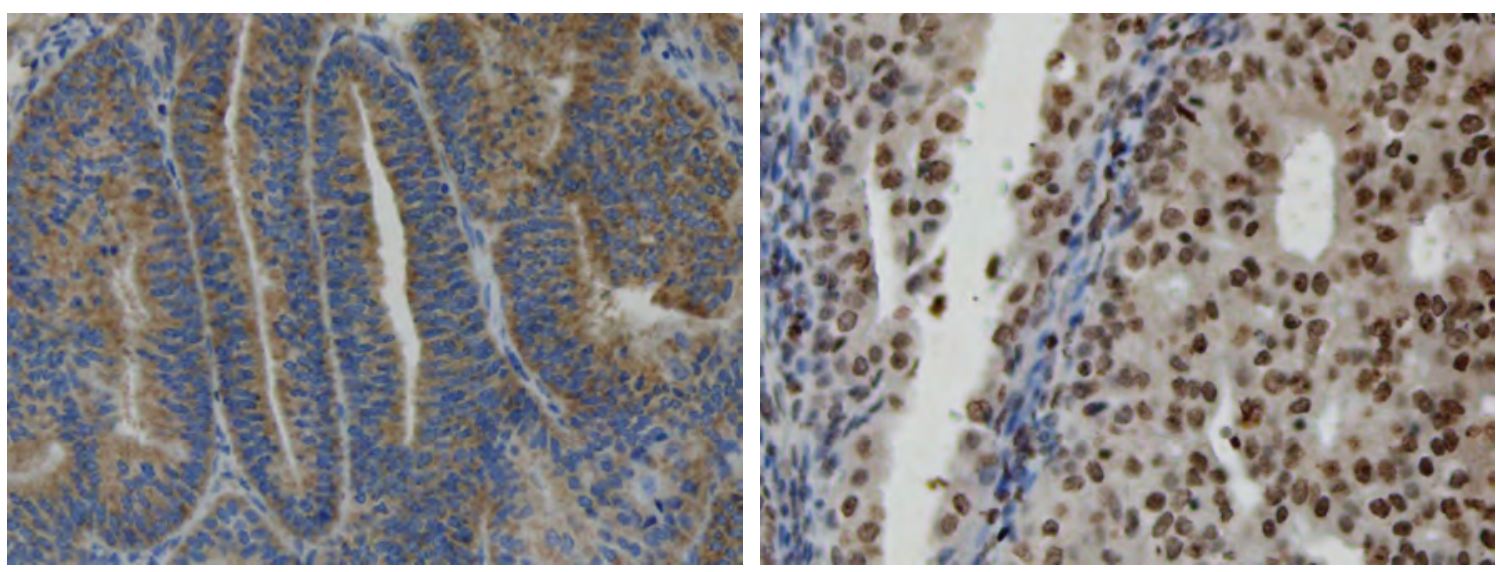

C
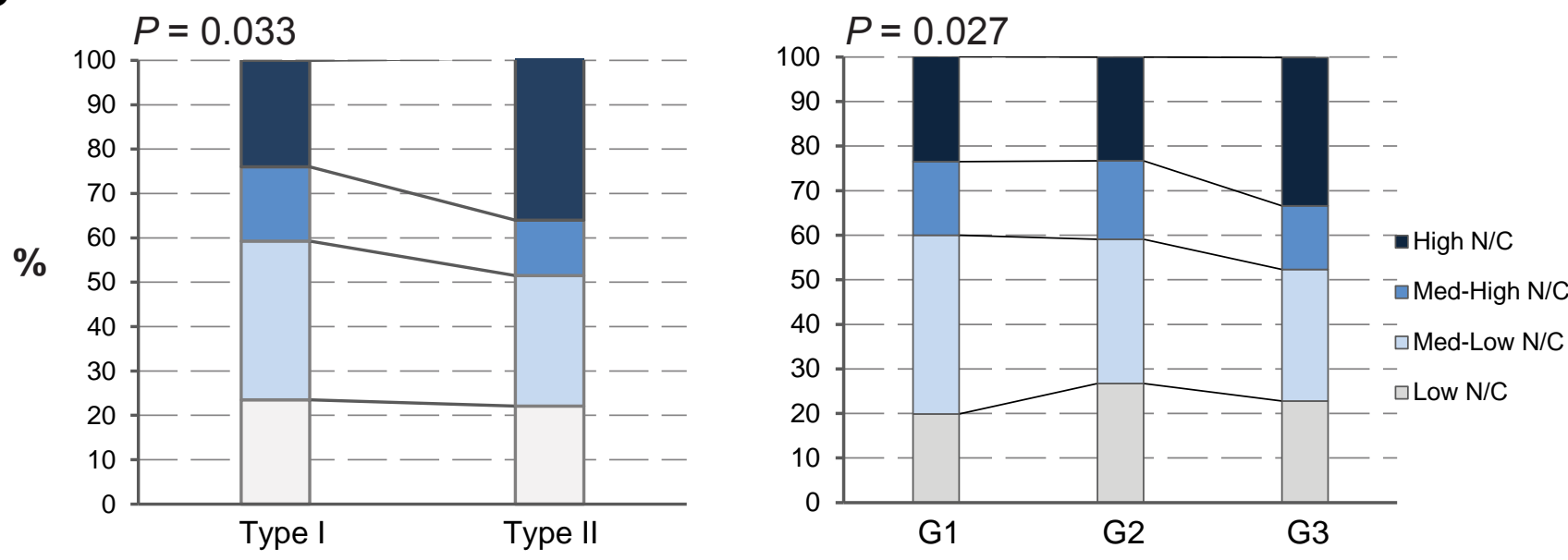
following p1 $10 \beta$ histochemistry of 714 patient histology samples. G represents the grade of the tumour. The number of samples per grade were as follows: G1= 267, G2= 210, G3= 237 .

\section{The levels of PtdIns(3,4,5) $P_{3}$ are increased in nuclei of EC cells in a p110 $\beta$-dependent} manner

We next determined if the presence of $\mathrm{p} 110 \beta$ in the nucleus correlated with nuclear PI3K pathway activity by first assessing the presence of active p-S473-AKT. As shown in Figure 2A, the cytoplasmic and nuclear levels of p-S473-AKT were low in EM, KLE, EFE-184 and MFE280 cells, while high levels were observed in PTEN-deficient cells, MFE-296, MFE-319, RL952 and Ishikawa cells, consistent with our previous study using total cell extracts in the same cells [47]. Interestingly, high nuclear p-S473-AKT levels were inversely correlated with low levels of p85 $\beta$ (Figure 1A). Furthermore, we determined the nuclear level of PtdIns $(3,4,5) P_{3}$ of all cells examined following nuclear isolation, lipid extraction, and detection with GST-GRP1PH, a PtdIns $(3,4,5) P_{3}$ specific probe ([48] Figure 2B and Supplementary Figure S1 showing the specificity of the probe). The purity of the fractionation was verified by Western immunoblotting using markers for the cytoplasm, nucleus and endoplasmic reticulum (Supplementary Figure S2). PtdIns(3,4,5) $P_{3}$ levels were high in most cancer cells and highest in RL95-2 cells compared to EM cells (Figure 2C). To test if p110 $\beta$ is responsible for the synthesis of nuclear PtdIns(3,4,5) $P_{3}$, we treated the PTEN-deficient cell line RL95-2 with TGX221, a p110 $\beta$ selective inhibitor. Treatment for 3 days reduced the levels of nuclear PtdIns(3,4,5) $P_{3}$ (Figure 2D) as well as nuclear p-S473-AKT (Figure 2E). However, the levels of total AKT were increased in the cytoplasm while it was decreased in the nucleus following p1 $10 \beta$ inhibition. The decrease in nuclear p-AKT may hence be due to loss of translocation of active pAKT from the cytoplasm. Knockdown of p110 $\beta$ also led to a decrease in the nuclear levels of PtdIns(3,4,5) $P_{3}$ and p-S473-AKT (Figure 2F-G).

\section{Figure 2 legend: Nuclear PtdIns(3,4,5) $P_{3}$ levels are elevated in endometrial cancer cells}

(A) Actively growing cells were fractionated into cytoplasmic and nuclear fractions. Equal protein concentrations were resolved by SDS-PAGE and analysed by Western immunoblotting using the antibodies as indicated. (B) PIP array spotted with 1.56 to 100 picoM of each of the seven PPIn species incubated with GST-GRP1-PH and an anti-GST-HRP conjugated antibody. (C) PtdIns(3,4,5) $P_{3}$ (PIP3) detection from nuclear acidic lipids extracted from actively growing cells, by overlay assay with GST-GRP1-PH domain and anti-GST-HRP conjugated antibody 
Figure 2

A

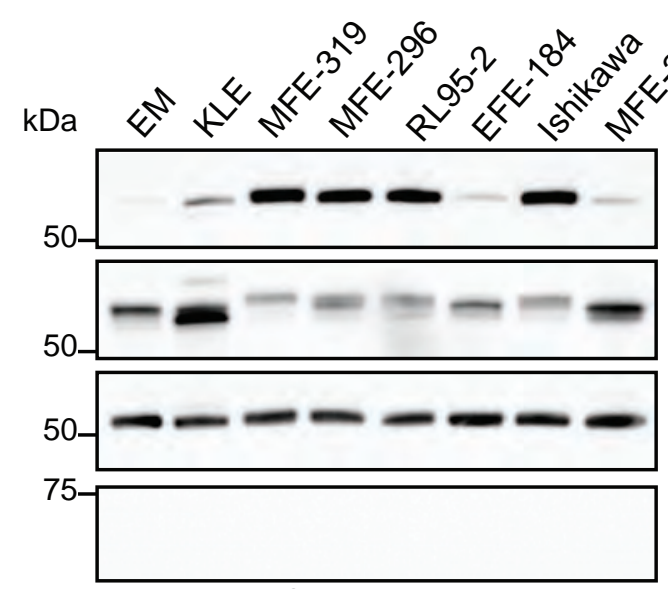

Cytoplasm

B

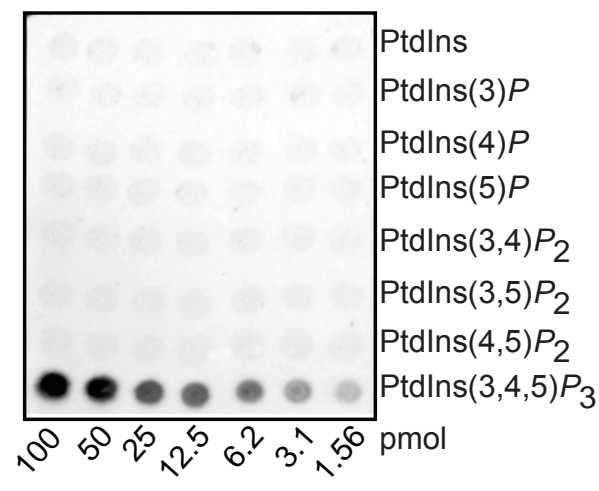

D

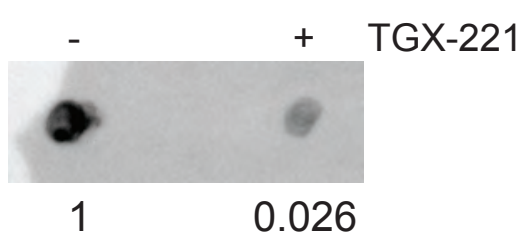

E

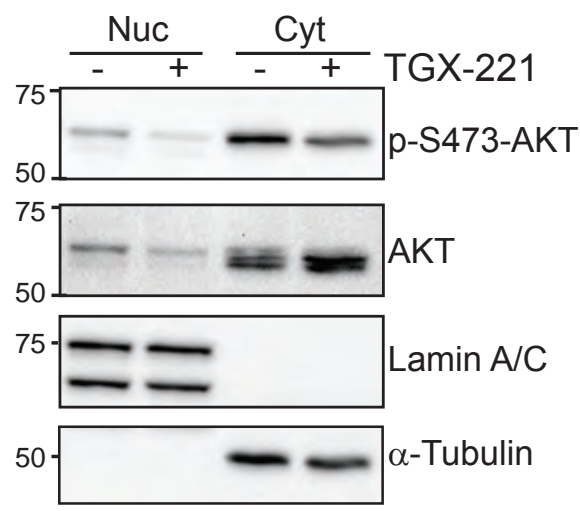

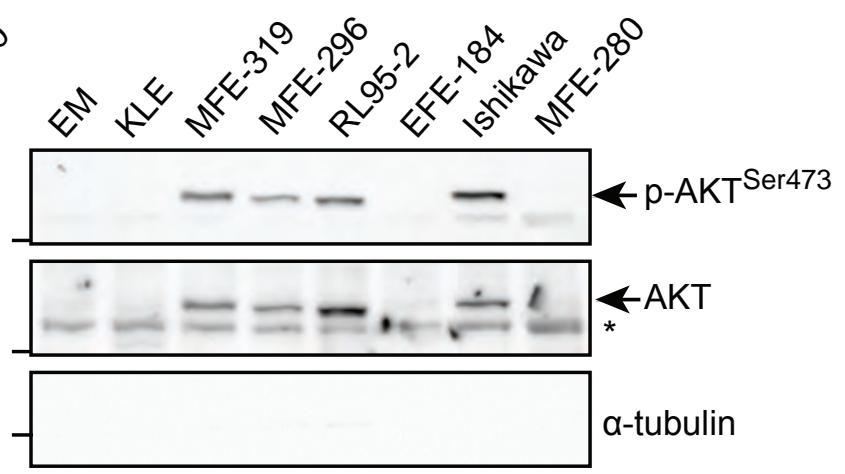

$=-m-m-m-m$ Lamin A/C

\section{Nucleus}

C

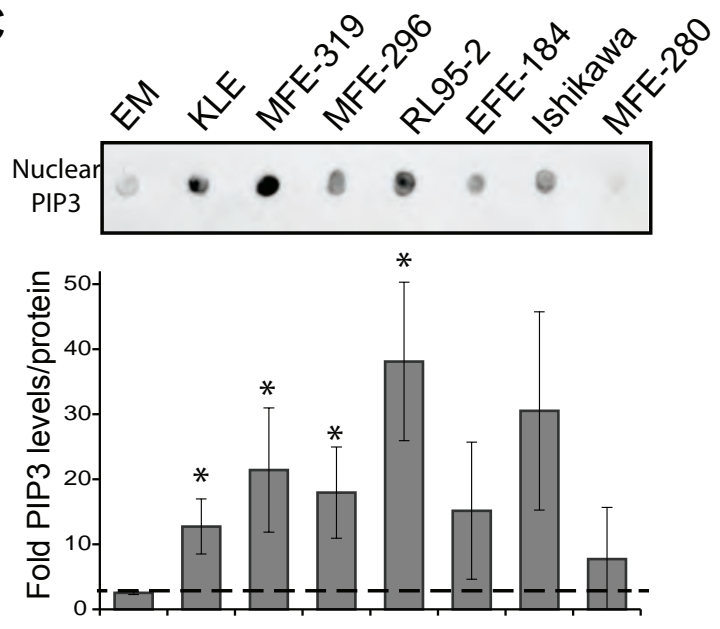

F

$+\quad$ si p110 $\beta$

G

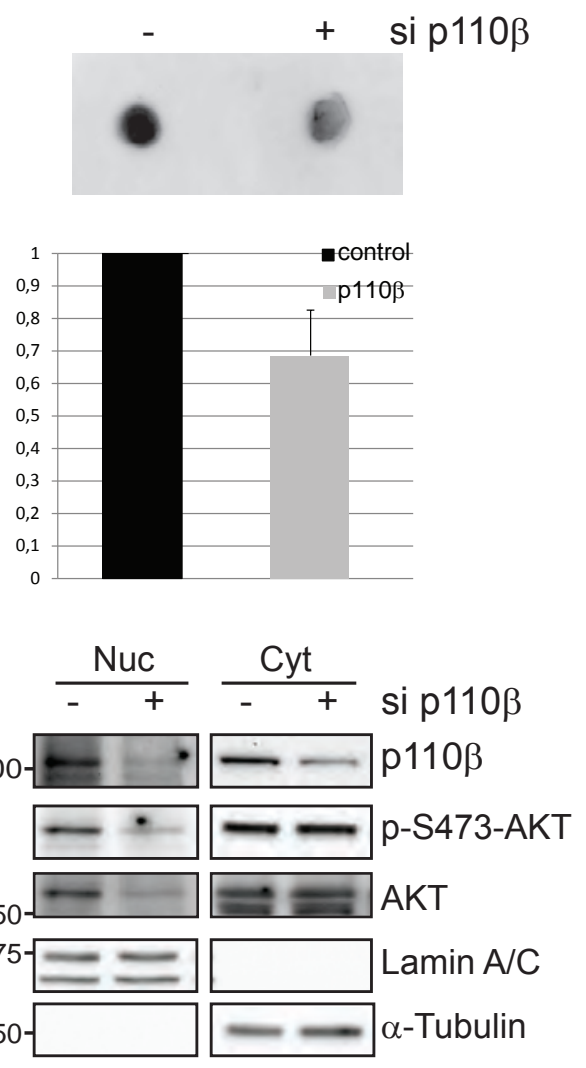


(upper panel). PIP3 signal/mg nuclear protein were calculated and expressed as folds compared to EM values (lower panel-graph. $\mathrm{n}=3{ }^{*} \mathrm{p}<0.05$ T-test). (D) PIP3 detection by overlay assay with GST-GRP1-PH domain and anti-GST-HRP conjugated antibody from nuclear acidic lipids extracted from RL95-2 cells treated with or without $10 \mu \mathrm{M}$ TGX-221 for three days. (E) Western immunoblotting of cytoplasmic (cyt) and nuclear (nuc) fractions from RL95-2 cells treated with or without $10 \mu \mathrm{M}$ TGX-221 for three days. (F) PIP3 detection by overlay assay with GST-GRP1-PH domain and anti-GST-HRP conjugated antibody from nuclear acidic lipids extracted from RL95-2 cells treated with $200 \mathrm{~nm}$ control or p110 $\beta$ siRNA. (G) Western immunoblotting of cytoplasmic (cyt) and nuclear (nuc) fractions from RL95-2 cells treated with $200 \mathrm{nM}$ control or $\mathrm{p} 110 \beta$ siRNA.

\section{p110 $\beta$ and PtdIns $(3,4,5) P_{3}$ are nucleolar in EC cells}

Consistent with our previous study [29], we found that p110 $\beta$ was localized in the cytoplasm, the nucleoplasm and strongly in nucleoli together with the nucleolar protein nucleophosmin in three cell lines (Figure 3A) with high nuclear p110 $\beta$. The specificity of the anti-p110 $\beta$ antibody was validated by knockdown using siRNA (Figure 3B). Nucleolar fractionation of RL95-2 cells confirmed the presence of $p 110 \beta$ in the same compartments by Western immunoblotting (Figure 3C). $\alpha$-Tubulin, lamin A/C and fibrillarin were used as cytoplasmic, nuclear and nucleolar markers, respectively to validate the fractionation procedure. Lamin A/C was found in both the nucleoplasmic and nucleolar compartments as previously reported [49]. p110 $\beta$ was also detected with PtdIns $(3,4,5) P_{3}$ both in the nucleoplasmic and nucleolar compartments of RL95-2 (Figure 3D) and MFE-319 cells (Supplementary Figure S3). The specificity of the anti-PtdIns $(3,4,5) P_{3}$ antibody was validated by lipid overlay assays using PIP arrays and by competition with free lipids by immunofluorescence (Supplementary Figure S4). Hence, pre-incubation of the antibody with different PPIns showed that nucleoplasmic and nucleolar staining was abolished by the presence of PtdIns(3,4,5) $P_{3}$ but not by PtdIns3P and PtdIns(3,4)P $P_{2}$. Furthermore, AKT was found to colocalise with the nucleolar pool of p110 $\beta$ and its active p-S473 form with the nucleolar protein nucleophosmin as discrete foci (Figure 3E). 


\section{Figure 3}

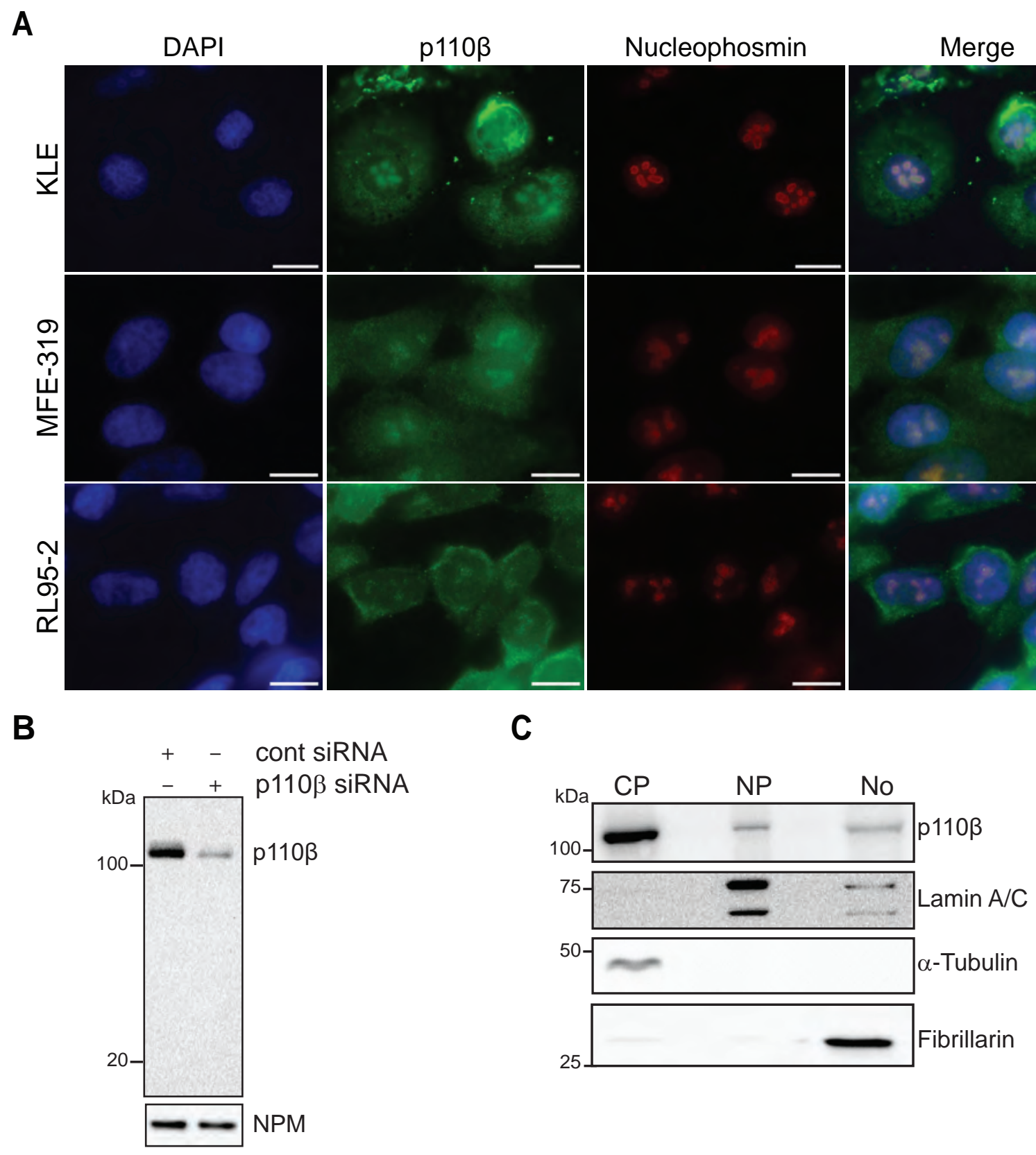

D

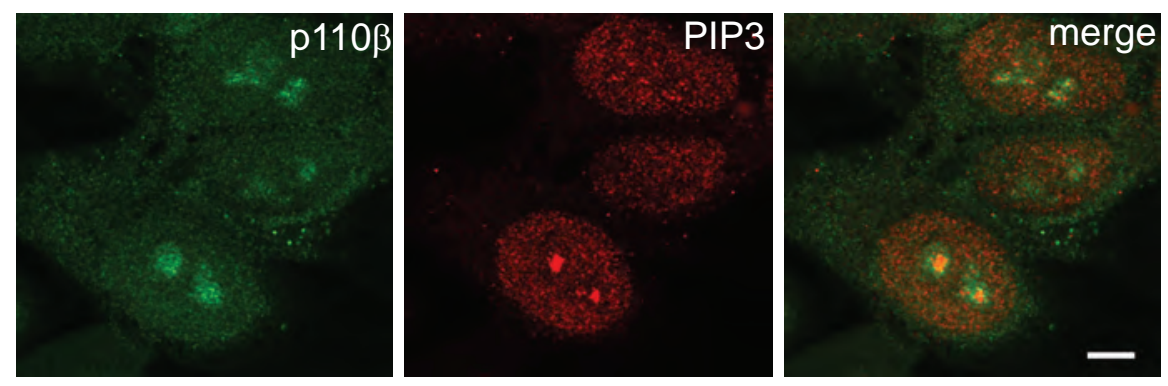

$\mathbf{E}$
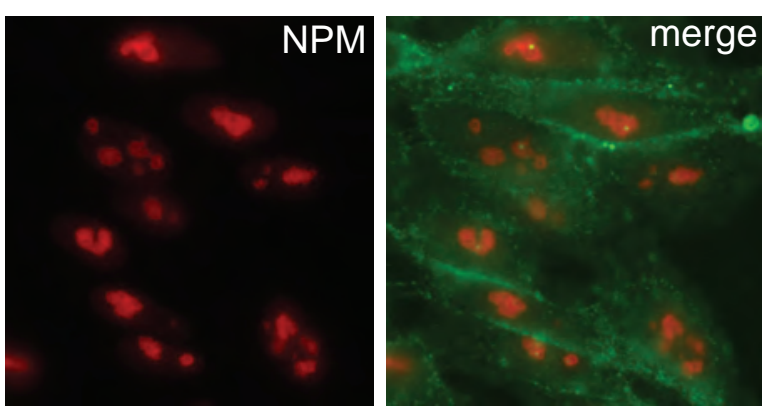


\section{Figure 3 legend: p110 $\beta$ and PtdIns(3,4,5) $P_{3}$ are nucleolar}

(A) Co-immunostaining of p110 $\beta$ using the abcam 151549 anti-p110 $\beta$ antibody and nucleophosmin in actively growing KLE, MFE-319 and RL95-2 cells and imaged by epifluorescence microscopy. Scale bar $10 \mu \mathrm{m}$ (x100). (B) Western immunoblotting of cell extracts from KLE cells treated with $100 \mathrm{nM}$ of control or $\mathrm{p} 110 \beta$ siRNA, using the abcam 151549 anti-p110 $\beta$ antibody. (C) Sub-cellular fractionation of RL95-2 cells and Western immunoblotting of equal protein amounts from each fraction (D-E) Confocal microscopy of actively growing RL95-2 cells co-stained with the indicated antibodies (Scale bar $5 \mu \mathrm{m}$ ).

\section{The nucleolar pool of PtdIns(3,4,5) $P_{3}$ is partly dependent upon the activity of p110}

The main function of the nucleolus is to synthesise ribosomes, requiring rRNA transcription, processing and assembly with ribosomal proteins [50]. rRNA transcription oscillates during the cell cycle, as it is lowest during mitosis and is re-activated in G1 phase with highest activity thereafter in S and G2 phases [51]. In parallel, p110 $\beta$ is activated during G1 in the nucleus and contributes to $\mathrm{G} 1$ to $\mathrm{S}$ phase transition $[26,27]$ and we have found that $\mathrm{p} 110 \beta$, localises dynamically in nucleoli when they start to reform as the cells exit mitosis (Supplementary Figure S5). To determine if the pool of PtdIns $(3,4,5) P_{3}$ present in nucleoli is produced due to the kinase activity of p110 , we compared the nucleolar appearance of $\operatorname{PtdIns}(3,4,5) P_{3}$ in WT and p110 $\beta$ kinase inactive mouse embryonic fibroblast (MEF) cells during the reformation of nucleoli as cells exit mitosis (Figure 4A). We combined nocodazol treatment and mitotic shakeoff to synchronize and enrich for mitotic cells. After plating the collected mitotic cells on coverslips, the cells were left to recover for 4-5 h before they were fixed and labelled with a GFP-GRP1-PH probe and immunostained with anti-nucleophosmin. In line with our results in HeLa cells (Supplementary Figure S5), PtdIns(3,4,5) $P_{3}$ was detected together with nucleophosmin in the p110 $\beta$ WT MEFs. In contrast, the p110 $\beta$ kinase inactive MEFs demonstrated a substantial decrease in PtdIns(3,4,5) $P_{3}$ nucleolar staining.

\section{High nucleolar p110ß levels correlates with high 47S rRNA transcription}

Elevated levels of nucleolar activity have been correlated to an increased risk of cancer development [52]. We next examined whether EC cells with high levels of p110 $\beta$ and PtdIns(3,4,5) $P_{3}$ in the nucleus had high level of 47S rRNA transcription compared to EM cells by quantitative RT-PCR. Consistently, all EC cell lines examined demonstrated higher levels compared to EM cells, with KLE cells, showing the highest levels (Figure 4B). Using a selective 
Figure 4

A

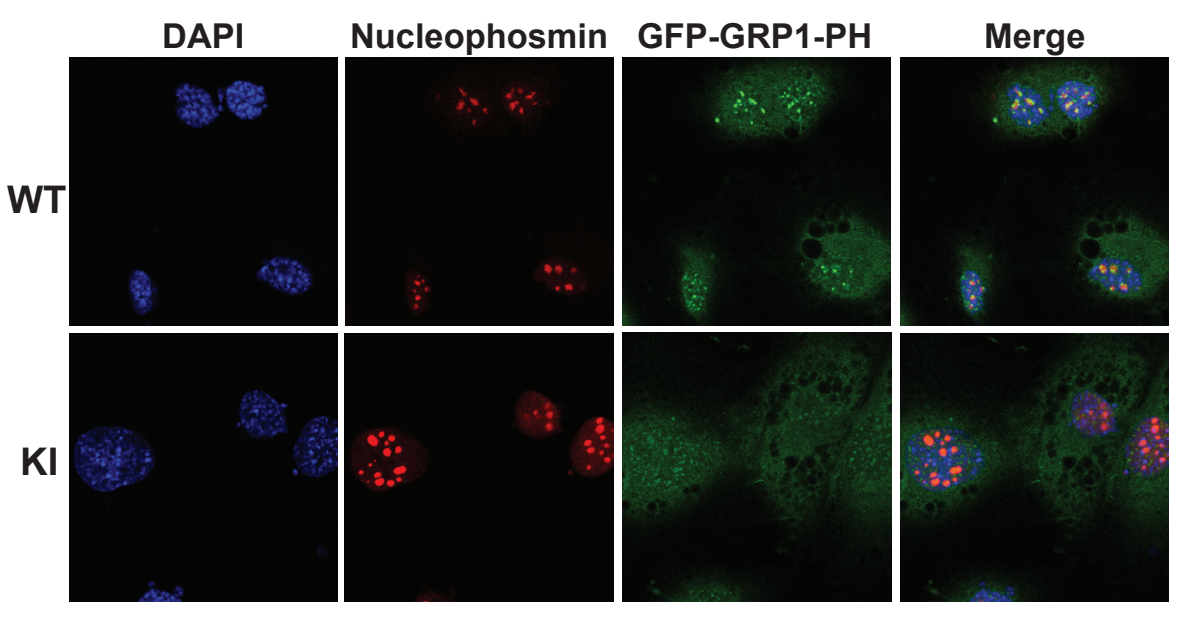

B

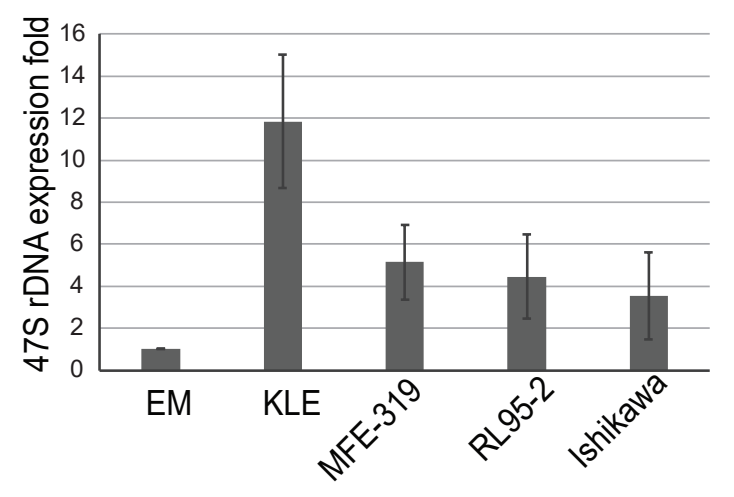

C

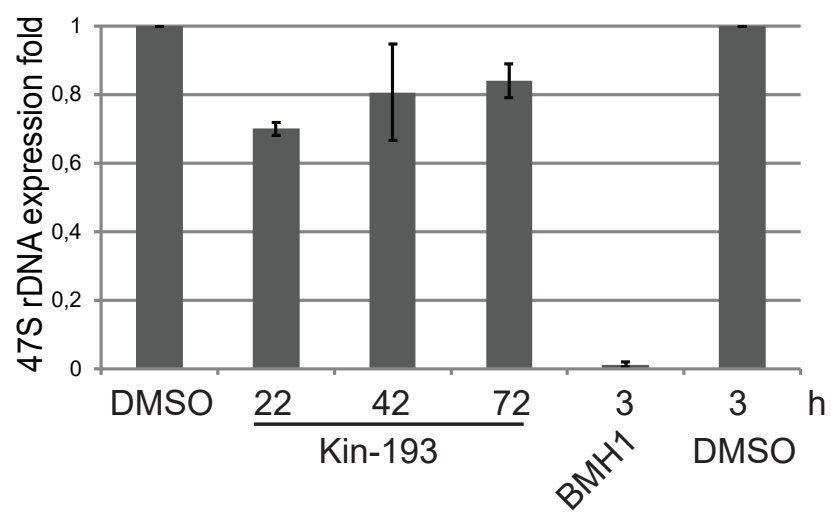


inhibitor of p110 3 , we next tested if $\mathrm{p} 110 \beta$ is implicated in $47 \mathrm{~S}$ transcription. A $30 \%$ decrease was observed following $22 \mathrm{~h}$ of treatment respectively while RNA Pol I inhibition almost completely blocked transcription (Figure 4C).

Figure 4 legend: $p 110 \beta$ is active in the nucleolus and contributes to $47 \mathrm{~S}$ pre-rRNA transcription

(A) MEFs p1 $10 \beta \mathrm{WT}$ and Kinase inactive (KI) were treated for $16 \mathrm{~h}$ with $50 \mathrm{ng} / \mathrm{ml}$ nocodazole, collected after mitotic shake-off and replated. Cells were fixed after $4 \mathrm{~h}$ and immunofluorescence staining was performed as indicated followed by confocal microscopy. (B) Relative 47S pre-rRNA to $\beta$-ACTIN mRNA expression in RL95-2, MFE 319, Ishikawa and EM cells. The expressions of all samples were normalized to EM cells. (C) Relative 47S prerRNA to $\beta$-ACTIN mRNA expression in RL95-2 treated in the presence of DMSO or the p110 $\beta$ inhibitor KIN-193 (10 $\mu \mathrm{M})$ for 22, 42 and $72 \mathrm{~h}$, or the BMH21 (1 $\mu \mathrm{M})$ for $3 \mathrm{~h}$.

\section{Discussion}

Cellular compartmentalisation provides an additional important mode of regulation for signalling cascades to achieve specificity and to precisely coordinate cellular outputs. The PI3K pathway has been extensively studied from a cytoplasmic perspective. However, a few studies have detailed the distinct intracellular localisation of PI3K enzymes. The PI3K p110 $\alpha$ is found to be restricted to the cytoplasm while $\mathrm{p} 110 \beta$ is present both in the cytoplasm and the nucleus, and in particular in the nucleoplasm, the chromatin fraction and the nucleolus [27-29]. The compartmentalisation of these enzymes is likely to impact signalling networks and to mediate different cell functions, hence accounting for the pleiotropic effects attributed to PI3K signalling. Although the PI3K signalling pathway is pivotal in cancer, the impact of the subcellular localisation of PI3K in processes attributed to tumourigenesis is still poorly understood. Our findings demonstrate for the first time that $\mathrm{p} 110 \alpha$ and $\mathrm{p} 110 \beta$ are differently compartmentalised in EC cells. Consistent with previous studies in other cell types [27, 28], $\mathrm{p} 110 \alpha$ is cytoplasmic while $\mathrm{p} 110 \beta$ is both cytoplasmic and nuclear. This would suggest that, in the cytoplasm, $\mathrm{p} 110 \alpha$ and $\mathrm{p} 110 \beta$ isoforms can share some of the functions attributed to PI3K signalling operating perhaps due to their reported cross-activation [53]. In cancer cells, the presence of genetic mutations affecting PIK3CA or PTEN would influence PtdIns(3,4,5) $P_{3-}$ mediated downstream functions induced by $\mathrm{p} 110 \alpha$ and $\mathrm{p} 110 \beta$ respectively in this compartment. Concerning the nucleus, we found that the levels of $\mathrm{p} 110 \beta$ are high in the nucleus of EC cell 
lines compared to EM cells. In clinically annotated tumour samples, we showed a correlation between the nuclear $\mathrm{p} 110 \beta$ levels and endometrial cancer progression as tumours with higher grade presented high $\mathrm{p} 110 \beta$ nuclear to cytoplasmic ratio. These results would indicate the importance of the levels of this isoform combined with its compartmentalisation status. At least, this would be consistent with the fact that the overexpression of p110 $\beta$ has previously been shown to lead to cell transformation in its wild type state [23]. However, this is the first study showing the potential importance of an increase in the nuclear compartmentalisation of p110 $\beta$ during disease progression in clinical samples.

Furthermore, our studies demonstrate that EC cells, not only have high nuclear levels of p110 $\beta$, but also elevated levels of PtdIns(3,4,5) $P_{3}$, its lipid product as well as the active form of the oncoprotein AKT, p-S473-Akt, the key signalling effector of PtdIns(3,4,5) $P_{3}$. Here, we demonstrate that upon p1 $10 \beta$ inhibition, the levels of p-S473-Akt were decreased in EC nuclei. The nuclear PtdIns $(3,4,5) P_{3}$ levels were also reduced in these cells following p110 $\beta$ inhibition, which suggests that the nuclear pool of PtdIns $(3,4,5) P_{3}$ is, at least partly, the product of the kinase activity of p110ß. Another pool could be dependent upon the activity of inositol polyphosphate kinase (IPMK). IPMK was initially discovered as an inositol(1,4,5)triphosphate kinase but was thereafter reported to also act on PPIn to generate PtdIns $(3,4,5) P_{3}[54,55]$. The existence of a molecular link within the nucleus between PtdIns(3,4,5) $P_{3}$ and Akt is however not clear from this study. Additional mechanisms of regulation required for the activation of Akt were not explored. These may include the PtdIns(3,4,5)P3-dependent activation of PDK1 and mTORC2, known to be critical for the phosphorylation and full activation of Akt. This may be plausible as they have been detected in the nucleus in previous studies [56-59].

A clear relationship between elevated nucleolar activity and increased risk of cancer has been shown [52]. Thus, nucleolar processes need to be tightly regulated with high fidelity to ensure appropriate cell growth and proliferation in response to external signals. One potential molecular link regulating these processes is the PI3K pathway. Previous studies have shown that the transcription and processing of the pre rRNA is stimulated in a PI3K and mTORdependent manner [60-62]. However, the responsible PI3K isoform was not identified in those studies. Interestingly, the PtdIns(3,4,5) $P_{3}$ effector protein nucleophosmin [63] as well as mTORC1 are known to localize to the nucleolus, where they were shown to regulate nucleolar function [62, 64-66]. Nuclear Akt has also been shown to regulate rRNA transcription by activating the TIF-I transcription factor [67]. This would correlate well with our findings detecting pAKT in the nucleolus. These studies would suggest that the key members of the PI3K pathway are present in the nucleolus but how PI3K, Akt and mTOR are activated in a 
nucleolar context, i.e. in a membrane-less environment is however unclear. In this study, we showed that both PtdIns(3,4,5) $P_{3}$ and p110 $\beta$ were localised in the nucleolar compartment, raising the possibility of $\mathrm{p} 110 \beta$ acting as a regulator of nucleolar functions in a kinasedependent manner. Preliminary data showed the detection of the PtdIns(3,4,5)P3 C38:4 molecular species from isolated nucleoli of RL95-2 cells by LC-MS/MS analyses (data not shown), which is consistent with the reported most common chemical form of fatty acyl chains for polyphosphoinositides (PPIn) [68-70]. Immunofluorescent staining indicated also of the presence of both total Akt and phosphorylated Akt in nucleoli, which can suggest a local activation of this protein by PtdIns $(3,4,5) P_{3}$ present in nucleoli. Again, this would need to be explored further, in particular in terms of the biophysical state of $\operatorname{PtdIns}(3,4,5) P_{3}$ in a membrane-less environment.

Our findings demonstrate that the RL95-2 endometrial cancer cells, high in nuclear PtdIns(3,4,5) $P_{3}$ and $p 110 \beta$ levels, have significantly increased pre-rRNA transcription. The proliferation of these cells was shown to be at least partly dependent upon the activity of p1 $10 \beta$ [47]. This would suggest that an increase in ribosome production will help increase cell proliferation and subsequently cancer progression. Nucleolar p110 $\beta$ would hence provide a mode of regulation of ribosome synthesis necessary for protein synthesis and ultimately cell division. $\mathrm{p} 110 \beta$ can therefore potentially increase tumour progression in EC cells by producing the nucleolar pool of PtdIns(3,4,5) $P_{3}$ and thereby increasing the biogenesis of ribosomes required for tumour growth. However, the exact molecular mechanisms by which PtdIns $(3,4,5) P_{3}$ or $\mathrm{p} 110 \beta$ can influence nucleolar function remains to be further explored.

\section{Materials and methods}

\section{Reagents}

Antibodies used in Western immunoblotting and immunostaining are listed in Supplementary Table S1. The selective p110 $\beta$ inhibitors TGX-221 (Cayman chemicals) and KIN-193 (aka AZD6482, from Selleckchem) were dissolved in DMSO at $10 \mathrm{mM}$ and stored at $-80^{\circ} \mathrm{C}$. The RNA polymerase I inhibitor, BMH21 (from Selleckchem) was dissolved in DMSO at $1 \mathrm{mM}$. PIK3CB (sc-37269) and control non-targeting (sc-37269C) siRNA and transfection reagent were from Santa Cruz. The pGEX-4T1-EGFP-GRP1-PH plasmid was from Dr Julien Viaud (INSERM U.1048, Toulouse, France). 


\section{Protein expression and purification}

The pGEX-4T1-EGFP-GRP1-PH plasmid was transformed into E. coli BL21-RIL DE3. The bacteria were grown at $37^{\circ} \mathrm{C}$ and further induced with $0.5 \mathrm{mM}$ isopropyl- $\beta$-Dthiogalactopyranoside overnight at $18^{\circ} \mathrm{C}$. Bacterial pellets were lysed in $50 \mathrm{mM}$ Tris $\mathrm{pH} 7.5$, $150 \mathrm{mM} \mathrm{NaCl}$, 1\% Triton-X100, 5 mM DTT, $10 \%$ glycerol containing protease inhibitor cocktail and $0.5 \mathrm{mg} / \mathrm{ml}$ lysozyme, for $30 \mathrm{~min}$ on ice. Following sonication and centrifugation, GST-EGFP-GRP1-PH was purified with glutathione-agarose 4B beads, analysed by SDSPAGE and Coomassie staining.

\section{Cell lines and cell culture conditions}

Cancer cell lines were obtained from ATCC (KLE, RL95-2), DSMZ Germany (MFE-296, MFE-319, EFE-184 and MFE-280) and Sigma-Aldrich (Ishikawa). EM-E6/E7-hTERT (EM), a non-transformed endometrial cell line isolated from glandular endometrial tissue and immortalized with E6/E7 and human TERT [71, 72], was a gift from Professor PM Pollock (University of Queensland, Australia). All cells were authenticated by short tandem repeat DNA profiling (IdentiCell Service, Dept. Molecular Medicine, Aarhus University Hospital, Denmark for all cancer cell lines and MD Anderson Cancer Center, USA for EM cells), as previously described [47]. $\mathrm{p} 110 \beta^{\mathrm{D} 931 \mathrm{~A} / \mathrm{D} 931 \mathrm{~A}}$ kinase inactive and $\mathrm{p} 110 \beta^{\mathrm{WT} / \mathrm{WT}}$ MEFs immortalised by Shp53 were from Dr Julie Guillermet-Guibert (Université Toulouse III-Paul Sabatier, Toulouse, France). All EC cells, HeLa and MEFs were cultured in Dulbecco's modified Eagle's medium (DMEM) supplemented with 10\% foetal bovine serum (FBS) and antibiotics (100 IU/ml penicillin and $100 \mu \mathrm{g} / \mathrm{ml}$ streptomycin). EM cells were cultured in DMEM/Ham's F12 supplemented with Insulin-Transferrin-Selenium, 10\% FBS and antibiotics and changed to DMEM containing 10\% FBS and antibiotics $24 \mathrm{~h}$ before harvest. Cells were harvested when they reached a maximum of $80 \%$ confluence.

\section{Cell synchronization}

Cells grown up to $70 \%$ confluency were treated with $50 \mathrm{ng} / \mathrm{mL}$ of nocodazole for $16 \mathrm{~h}$. The mitotic cells were collected by mechanical shake-off (repeated twice). The cells were pelleted by centrifugation at $70 \mathrm{~g}$ for $5 \mathrm{~min}$. After washing the pellet twice with $10 \mathrm{ml}$ of growth medium the cell pellet was plated on coverslips covered with poly-L-Lysine. The cells were collected at different time points after re-plating. 


\section{Whole cell extracts, subcellular fractionation and Western immunoblotting}

Whole cell extracts were prepared in radioimmunoprecipitation assay (RIPA) lysis buffer (50 $\mathrm{mM}$ Tris pH 8.0, 0.5\% deoxycholic acid, $150 \mathrm{mM} \mathrm{NaCl,} \mathrm{1 \%} \mathrm{NP-40,} \mathrm{0.1 \%} \mathrm{SDS)} \mathrm{supplemented}$ with 5 mM NaF, 2 mM Na3VO 4 and 1x Sigma Protease Inhibitor Cocktail. Nuclear fractionation was carried out according to O'Caroll et al. [73] and nuclear pellets were lysed in RIPA buffer. RL95-2 cells required an additional syringing step of the nuclear pellet resuspended in wash buffer (10 mM Tris-HCl pH 7.5 and $2 \mathrm{mM} \mathrm{MgCl}_{2}$ ) to avoid cytoplasmic contamination. The nucleolar fractionation was performed according to the protocol described in Lam et al with minor changes [74]. In brief, cells were grown in 10 x $15 \mathrm{~cm}$ dishes up to $70 \%$ confluency. Fresh medium was added to the cells $1 \mathrm{~h}$ prior to the fractionation. Cells were trypsinized and washed three times with cold PBS. The cell pellet was collected by centrifugation and resuspend in $5 \mathrm{ml}$ of buffer A containing $10 \mathrm{mM}$ HEPES pH 7.9, $1.5 \mathrm{mM} \mathrm{MgCl} 2,10 \mathrm{mM} \mathrm{KCl,} 1$ \% Igepal and protease inhibitor cocktail. After $5 \mathrm{~min}$ of incubation on ice, the cells were syringed 16 times using a 23-gauge needle. After centrifugation at $200 \mathrm{~g}$ for $5 \mathrm{~min}$ at $4^{\circ} \mathrm{C}$ the supernatant was collected as the cytosolic fraction and the nuclear pellet was re-suspended in 3 $\mathrm{ml}$ of buffer $\mathrm{S} 1$ ( $0.25 \mathrm{M}$ sucrose, $10 \mathrm{mM} \mathrm{MgCl}_{2}$ and protease inhibitor cocktail). The suspension was layered over $3 \mathrm{ml}$ of buffer S2 $(0.35 \mathrm{M}$ sucrose, $0.5 \mathrm{mM} \mathrm{MgCl} 2$ and protease inhibitor cocktail) and centrifugation was performed at $1400 \mathrm{~g}$ for $5 \mathrm{~min}$ at $4^{\circ} \mathrm{C}$. The pellet was then resuspended in $3 \mathrm{ml}$ of buffer S2 and sonicated (7 times: $10 \mathrm{sec}$ on/10sec off) on ice. The lysate was then layered over $3 \mathrm{ml}$ of buffer S3 (0.88 M Sucrose, $0.5 \mathrm{mM} \mathrm{MgCl} 2$ and protease inhibitor cocktail) and centrifugation was performed at $3000 \mathrm{~g}$ for $10 \mathrm{~min}$ at $4^{\circ} \mathrm{C}$. The top layer was collected as the nucleoplasmic fraction and the pellet which contained the nucleoli was washed once with $500 \mu \mathrm{l}$ of S2 and centrifuged. Nucleolar pellets were resuspended in RIPA buffer. Equal amount of proteins (40-50 $\mu \mathrm{g})$ were resolved on denaturing SDS-polyacrylamide gels, immunoblotted on to $0.45 \mu \mathrm{m}$ thick nitrocellulose membranes and detected by enhanced chemiluminescence using the SuperSignal West Pico Chemiluminescent Substrate (ThermoFisher) and visualized with a BioRad ChemiDocTM Xrs+.

\section{RNA extraction and reverse transcription}

Cells were pelleted, washed two times with PBS and resuspended in $1 \mathrm{ml}$ TriReagent (Sigma) and incubated at room temperature for $5 \mathrm{~min}$. $200 \mu \mathrm{l}$ of chloroform was added, mixed vigorously, incubated at room temperature for $1 \mathrm{~min}$ and centrifuged at $12000 \mathrm{~g}$ and $4^{\circ} \mathrm{C}$ for 15 min. Phenol-chloroform-isoamyl alcohol mixture (Sigma) was added (500 $\mu$ l) to the upper phase, mixed, incubated at room temperature for $2 \mathrm{~min}$ and centrifuged at $12000 \mathrm{~g}$ and $4^{\circ} \mathrm{C}$ for 
$10 \mathrm{~min}$. Chloroform $(500 \mu \mathrm{l})$ was added to the upper phase, mixed, incubated at room temperature for $1 \mathrm{~min}$ and centrifuged at $12000 \mathrm{~g}$ and $4^{\circ} \mathrm{C}$ for $10 \mathrm{~min} .20 \mu \mathrm{g}$ of RNA grade glycogen (Thermo Fisher Scientific) and $500 \mu \mathrm{l}$ isopropanol were added to the upper phase, mixed and incubated at room temperature for $20 \mathrm{~min}$ before centrifuging at $13000 \mathrm{~g}$ and $4^{\circ} \mathrm{C}$ for $20 \mathrm{~min}$. The pellet was resuspended in $1 \mathrm{ml}$ of ice cold ethanol (70\%) and centrifuged (at $8000 \mathrm{~g}$ and $4^{\circ} \mathrm{C}$ ) for $5 \mathrm{~min}$. The extracted RNA was dissolved in RNAse-free water for RTqPCR analysis. cDNA was generated from $1 \mu \mathrm{g}$ of RNA using random primers according to the protocol from the High-Capacity cDNA Reverse Transcription Kit (Thermo Fisher scientific) with RNase Inhibitor.

\section{Real time qPCR}

Real-time qPCR was performed from three biological replicates in triplicates on the Roche Light Cycler 480 using PowerUp ${ }^{\mathrm{TM}} \mathrm{SYBR}^{\mathrm{TM}}$ Green Master Mix (Thermo Fisher scientific or Life Sciences). The reaction mix contained $10 \mu \mathrm{M}$ of each primer and $1 \mathrm{ng}$ of cDNA diluted. The primers used for the target human 47S-rRNA allow the amplification of the sequence (+302 and +548 ) spanning the first cleavage site positioned at +414 within the 5 ' external transcribed spacer region: 5'-GTGCGTGTCAGGCGTTCT-3' and 5'-GGGAGAGGAGCAGACGAG-3' [75]. The human $\beta$-ACTIN was used as a reference gene and the following primers were used, 5'-TGCGTCTGGACCTGGCTGGC-3' and 5'-GCCTCAGGGCAGCGGAACC-3' [76]. The cycling parameters from the manufacturers were followed. $58^{\circ} \mathrm{C}$ was used for the annealing step and 42 cycles were performed. Calibration curves based on five serial cDNA amounts (0.016, 0.08, 0.4, 2 and $10 \mathrm{ng} / \mu \mathrm{l})$ were used for calculation of the reaction efficiencies. The 47S-rRNA expression was normalised to that of $\beta$-ACTIN according to the $\mathrm{C}_{\mathrm{T}}\left(\mathrm{N}^{-\Delta \Delta \mathrm{Ct}}\right)$ method, were $\mathrm{N}$ represents the primer efficiency, measured in each experiment.

\section{Lipid Extraction from nuclear fractions}

Following cell fractionation, the nuclear pellets were resuspended in nuclear resuspension buffer (10 mM Tris pH 7,4, 1 mM EGTA, 1,5 mM KCL, 5 mM MgCL2, 320 mM sucrose) and the number of nuclei counted. Lipids were extracted from each nuclear fraction using a method adapted from Grey et al [77]. Nuclei were incubated in $1 \mathrm{~mL} \mathrm{MeOH/CHCl} 32: 1$ to extract neutral lipids for $10 \mathrm{~min}$ at room temperature with shaking at $1200 \mathrm{rpm}$ and vortexed 3-4 times. The samples were centrifuged at $3000 \mathrm{~g}$ for $5 \mathrm{~min}$ at $4{ }^{\circ} \mathrm{C}$ and supernatants were discarded and the same procedure was repeated. The acidic lipids were then extracted with $750 \mu \mathrm{L}$ 
$\mathrm{MeOH} / \mathrm{CHCl}_{3} / 0.1 \mathrm{M} \mathrm{HCl}$ 80:40:1 2:1:0.8 and incubated for $15 \mathrm{~min}$ at room temperature and vortexed 4 times during the incubation followed by centrifugation at $3000 \mathrm{~g}$ for $5 \mathrm{~min}$ at $4{ }^{\circ} \mathrm{C}$. The pellets were resuspended with $250 \mu \mathrm{L} \mathrm{CHCl}_{3}$ and $450 \mu \mathrm{L} 0.1 \mathrm{M} \mathrm{HCl}$ and centrifuged at $3000 \mathrm{~g}$ for $5 \mathrm{~min}$ at $4{ }^{\circ} \mathrm{C}$ and a phase split between the organic and aqueous phases was apparent. The organic phase (bottom phase) was collected in conical glass tubes and dried at $60^{\circ} \mathrm{C}$ under $\mathrm{N}_{2}$ gas. Lipids were resuspended with 4-6 $\mu \mathrm{l}$ of $\mathrm{MeOH} / \mathrm{CHCl} / \mathrm{H}_{2} \mathrm{O}$ 2:1:0.8, vortexed for 30 seconds before being sonicated in an ice bath for 5 min and vortexed again for 30 seconds. Proteins were recovered from lipid extraction and the protein concentration was estimated for validation of the fractionation by western blotting.

\section{Lipid Overlay Assay}

Lipids obtained from lipid extraction were spotted on Hybond ${ }^{\mathrm{TM}}$-CExtra membranes, $2 \mu \mathrm{l}$ at a time. The membranes were left to dry for 1 hour at room temperature protected from light. The membranes were next blocked for $1 \mathrm{~h}$ at room temperature with the appropriate blocking buffer (1\% fat-free milk in PBS pH 7.4) and further incubated with $0.5 \mu \mathrm{g} / \mathrm{mL}$ GST-GRP1-PH in the same buffer overnight at $4^{\circ} \mathrm{C}$ and protected from light. GST-GRP1-PH was expressed and purified as described previously [78]. The membranes were washed 6 x 5 min in PBS-T (0.05\% Tween 20) and then incubated with anti-GST conjugated to HRP (1:30 000) in blocking buffer for $1 \mathrm{~h}$ at room temperature. The blots were washed $6 \times 5$ min with PBS-T. The signal was detected by ECL using the SuperSignal West Pico Chemiluminescent Substrate or with SuperSignal West Femto Maximum Sensitivity Substrate (Thermo Fisher scientific) and detected with a BioRad ChemiDoc ${ }^{\mathrm{TM}}$ Xrs+. Lipid spot densitometry was quantified using ImageJ.

\section{Immunostaining and microscopy}

Cells grown on coverslips were fixed with 3.7\% paraformaldehyde/PBS for $10 \mathrm{~min}$, washed thrice with PBS, permeabilised with 0.25\% Triton X-100/PBS for $10 \mathrm{~min}$, blocked for $1 \mathrm{~h}$ with blocking buffer (3\% BSA in 0.05\% Triton X-100/PBS) and incubated with primary antibodies diluted in blocking buffer overnight at $4^{\circ} \mathrm{C}$ and subsequently with fluorescently-labelled secondary antibodies diluted in blocking buffer for $1 \mathrm{~h}$ at room temperature. For labelling with EGFP-GRP1-PH, cells were blocked in 3\% fatty-acid free BSA and 0.05\% Triton-X100 in PBS for $1 \mathrm{~h}$ at RT followed by incubation with $40 \mu \mathrm{g} / \mathrm{ml}$ of the probe in $1 \%$ fatty-acid free BSA and 0.05\% Triton-X100 in PBS for $2 \mathrm{~h}$ at RT. Washes were performed with 0.05\% Tween-20/PBS after antibody incubation. The coverslips were mounted in ProLong Gold Antifade Reagent 
containing 4',6-diamidino-2-phenylindole (DAPI) or without DAPI and DNA labelling was performed using Hoechst 33342. Images were acquired with a Leica DMI6000B fluorescence microscope using x40 or x100 objectives or Leica TCS SP5 confocal laser scanning microscope using a 63x/1.4 oil immersion lens. Images were processed with a Leica application suite V 4.0 and Adobe Photoshop CC 2018.

\section{Patient series and immunohistochemistry}

Tissue was collected from patients diagnosed with endometrial cancer at Haukeland University hospital during the period from 2001-2013 and included a total of 725 primary tumours (should we add more on the type/grade of the samples here?). Clinical data were collected as described earlier [79, 80]. The patient cohort used for $\mathrm{p} 110 \beta$ immunohistochemistry is described in detail in Tangen et al [80]. This study was conducted in line with Norwegian legislation and international demands for ethical review and was approved by the Norwegian Data Inspectorate, Norwegian Social Sciences Data Services and the Western Regional Committee for Medical and Health Research Ethics (REK 2009/2315, REK 2014/1907). Patients signed an informed consent. TMA sections were stained and scored for $\mathrm{p} 110 \beta$ expression following a protocol previously described [80]. Briefly, three cylinders of $0.6 \mathrm{~mm}$ were retrieved from high tumour purity areas using a custom-made precision instrument (Beecher Instruments, Silver Spring, MD, USA) and mounted in a paraffin block. TMA sections ( $5 \mu \mathrm{m})$ were stained for p110 $\beta$ expression and scored visually by light microscopy using 20x objective by two independent observers (CK and ILT). Scoring was performed blinded for information regarding clinical characteristics and outcome for the cytoplasmic and the nuclear areas. A semi quantitative and subjective scoring method was used, and a staining index was calculated as a product of the staining intensity score ( 0 , no staining; 1 , weak; 2 , moderate; and 3, strong) and the area of positive tumour cells score $(1 \leq 10 \%, 2=10-50 \%$ and $3 \geq 50 \%)$, leading to scores ranging from 0 to 9 . The ratio between the nuclear and the cytoplasmic scores was then calculated.

\section{Statistical analysis}

For clinical samples, statistical analyzes were performed using the software package SPSS 22 (SPSS Inc, Chicago, IL) and the values of $P<0.05$ were considered statistically significant. Correlations between groups were evaluated using the Mann-Whitney $U$ test for continuous variables. 


\section{Acknowledgments}

We thank Pamela Pollock (Queensland University of Technology, Brisbane, Australia) for providing the EM cells. This work was funded by the University of Bergen, the Norwegian cancer society (project number 2183087 to AEL and TK) and the Meltzer foundation (to FMG).

\section{Author contribution}

AEL, TK and FMG designed the experiments. TK, FMG, APM and VSA carried out most of the experiments and assisted in the analysis and interpretation of data. CK and ILT acquired and analysed immunohistochemistry data. DCT assisted in the acquisition of data. AEL and FMG wrote, extensively reviewed and revised the manuscript. AEL supervised the research.

\section{Competing interests}

The authors declare no competing interests.

\section{References}

1. $\quad$ Engelman, J. A., Targeting PI3K signalling in cancer: opportunities, challenges and limitations. Nat Rev Cancer 2009, 9, (8), 550-62.

2. Fruman, D. A.; Rommel, C., PI3K and cancer: lessons, challenges and opportunities. Nat Rev Drug Discov 2014, 13, (2), 140-56.

3. Thorpe, L. M.; Yuzugullu, H.; Zhao, J. J., PI3K in cancer: divergent roles of isoforms, modes of activation and therapeutic targeting. Nat Rev Cancer 2015, 15, (1), 7-24.

4. Vanhaesebroeck, B.; Stephens, L.; Hawkins, P., PI3K signalling: the path to discovery and understanding. Nat Rev Mol Cell Biol 2012, 13, (3), 195-203.

5. Manning, B. D.; Toker, A., AKT/PKB Signaling: Navigating the Network. Cell 2017, 169, (3), 381-405.

6. Salamon, R. S.; Backer, J. M., Phosphatidylinositol-3,4,5-trisphosphate: tool of choice for class I PI 3-kinases. Bioessays 2013, 35, (7), 602-11.

7. Hers, I.; Vincent, E. E.; Tavare, J. M., Akt signalling in health and disease. Cell Signal 2011, 23, (10), 1515-27.

8. Chalhoub, N.; Baker, S. J., PTEN and the PI3-kinase pathway in cancer. Annu Rev Pathol 2009, 4, 127-50.

9. Bi, L.; Okabe, I.; Bernard, D. J.; Nussbaum, R. L., Early embryonic lethality in mice deficient in the p110beta catalytic subunit of PI 3-kinase. Mamm Genome 2002, 13, (3), 169-72.

10. Bi, L.; Okabe, I.; Bernard, D. J.; Wynshaw-Boris, A.; Nussbaum, R. L., Proliferative defect and embryonic lethality in mice homozygous for a deletion in the p110alpha subunit of phosphoinositide 3-kinase. J Biol Chem 1999, 274, (16), 10963-8. 
11. Ciraolo, E.; Iezzi, M.; Marone, R.; Marengo, S.; Curcio, C.; Costa, C.; Azzolino, O.; Gonella, C.; Rubinetto, C.; Wu, H.; Dastrù, W.; Martin, E.; Silengo, L.; Altruda, F.; Turco, E.; Lanzetti, L.; Musiani, P.; Rückle, T.; Rommel, C.; Backer, J.; Forni, G.; Wymann, M.; Hirsch, E., Phosphoinositide 3-kinase p110beta activity: key role in metabolism and mammary gland cancer but not development. Science signaling 2008, 1, (36).

12. Guillermet-Guibert, J.; Bjorklof, K.; Salpekar, A.; Gonella, C.; Ramadani, F.; Bilancio, A.; Meek, S.; Smith, A. J.; Okkenhaug, K.; Vanhaesebroeck, B., The p110beta isoform of phosphoinositide 3-kinase signals downstream of $G$ protein-coupled receptors and is functionally redundant with p110gamma. Proc Natl Acad Sci U S A 2008, 105, (24), 8292-7.

13. Jia, S.; Liu, Z.; Zhang, S.; Liu, P.; Zhang, L.; Lee, S. H.; Zhang, J.; Signoretti, S.; Loda, M.; Roberts, T. M.; Zhao, J. J., Essential roles of PI(3)K-p110beta in cell growth, metabolism and tumorigenesis. Nature 2008, 454, (7205), 776-9.

14. Fritsch, R.; de Krijger, I.; Fritsch, K.; George, R.; Reason, B.; Kumar, M. S.; Diefenbacher, M.; Stamp, G.; Downward, J., RAS and RHO families of GTPases directly regulate distinct phosphoinositide 3-kinase isoforms. Cell 2013, 153, (5), 1050-63.

15. Samuels, Y.; Wang, Z.; Bardelli, A.; Silliman, N.; Ptak, J.; Szabo, S.; Yan, H.; Gazdar, A.; Powell, S. M.; Riggins, G. J.; Willson, J. K.; Markowitz, S.; Kinzler, K. W.; Vogelstein, B.; Velculescu, V. E., High frequency of mutations of the PIK3CA gene in human cancers. Science 2004, 304, (5670), 554.

16. Dbouk, H. A.; Khalil, B. D.; Wu, H.; Shymanets, A.; Nurnberg, B.; Backer, J. M., Characterization of a tumor-associated activating mutation of the p110beta PI 3-kinase. PLoS One 2013, 8, (5), e63833.

17. Pazarentzos, E.; Giannikopoulos, P.; Hrustanovic, G.; St John, J.; Olivas, V. R.; Gubens, M. A.; Balassanian, R.; Weissman, J.; Polkinghorn, W.; Bivona, T. G., Oncogenic activation of the PI3-kinase p110beta isoform via the tumor-derived PIK3Cbeta(D1067V) kinase domain mutation. Oncogene 2016, 35, (9), 1198-205.

18. Whale, A. D.; Colman, L.; Lensun, L.; Rogers, H. L.; Shuttleworth, S. J., Functional characterization of a novel somatic oncogenic mutation of PIK3CB. Signal Transduction And Targeted Therapy 2017, 2, 17063.

19. Torbett, N. E.; Luna-Moran, A.; Knight, Z. A.; Houk, A.; Moasser, M.; Weiss, W.; Shokat, K. M.; Stokoe, D., A chemical screen in diverse breast cancer cell lines reveals genetic enhancers and suppressors of sensitivity to PI3K isoform-selective inhibition. Biochem $J$ 2008, 415, (1), 97-110.

20. Wee, S.; Wiederschain, D.; Maira, S. M.; Loo, A.; Miller, C.; deBeaumont, R.; Stegmeier, F.; Yao, Y. M.; Lengauer, C., PTEN-deficient cancers depend on PIK3CB. Proc Natl Acad Sci U $S$ A 2008, 105, (35), 13057-62.

21. Ni, J.; Liu, Q.; Xie, S.; Carlson, C.; Von, T.; Vogel, K.; Riddle, S.; Benes, C.; Eck, M.; Roberts, T.; Gray, N.; Zhao, J., Functional characterization of an isoform-selective inhibitor of PI3Kp110beta as a potential anticancer agent. Cancer discovery 2012, 2, (5), 425-33.

22. Schmit, F.; Utermark, T.; Zhang, S.; Wang, Q.; Von, T.; Roberts, T. M.; Zhao, J. J., PI3K isoform dependence of PTEN-deficient tumors can be altered by the genetic context. Proc Natl Acad Sci U S A 2014, 111, (17), 6395-400. 
23. Kang, S.; Denley, A.; Vanhaesebroeck, B.; Vogt, P. K., Oncogenic transformation induced by the p110beta, -gamma, and -delta isoforms of class I phosphoinositide 3-kinase. Proc Natl Acad Sci U S A 2006, 103, (5), 1289-94.

24. Juric, D.; Castel, P.; Griffith, M.; Griffith, O. L.; Won, H. H.; Ellis, H.; Ebbesen, S. H.; Ainscough, B. J.; Ramu, A.; Iyer, G.; Shah, R. H.; Huynh, T.; Mino-Kenudson, M.; Sgroi, D.; Isakoff, S.; Thabet, A.; Elamine, L.; Solit, D. B.; Lowe, S. W.; Quadt, C.; Peters, M.; Derti, A.; Schegel, R.; Huang, A.; Mardis, E. R.; Berger, M. F.; Baselga, J.; Scaltriti, M., Convergent loss of PTEN leads to clinical resistance to a PI(3)Kalpha inhibitor. Nature 2014.

25. Benistant, C.; Chapuis, H.; Roche, S., A specific function for phosphatidylinositol 3-kinase alpha (p85alpha-p110alpha) in cell survival and for phosphatidylinositol 3-kinase beta (p85alpha-p110beta) in de novo DNA synthesis of human colon carcinoma cells. Oncogene 2000, 19, (44), 5083-90.

26. Marques, M.; Kumar, A.; Cortes, I.; Gonzalez-Garcia, A.; Hernandez, C.; Moreno-Ortiz, M. C.; Carrera, A. C., Phosphoinositide 3-kinases p110alpha and p110beta regulate cell cycle entry, exhibiting distinct activation kinetics in G1 phase. Mol Cell Biol 2008, 28, (8), 2803-14.

27. Marques, M.; Kumar, A.; Poveda, A. M.; Zuluaga, S.; Hernandez, C.; Jackson, S.; Pasero, P.; Carrera, A. C., Specific function of phosphoinositide 3-kinase beta in the control of DNA replication. Proc Natl Acad Sci U S A 2009, 106, (18), 7525-30.

28. Kumar, A.; Redondo-Munoz, J.; Perez-Garcia, V.; Cortes, I.; Chagoyen, M.; Carrera, A. C., Nuclear but not cytosolic phosphoinositide 3-kinase beta has an essential function in cell survival. Mol Cell Biol 2011, 31, (10), 2122-33.

29. Karlsson, T.; Altankhuyag, A.; Dobrovolska, O.; Turcu, D. C.; Lewis, A. E., A polybasic motif in ErbB3-binding protein 1 (EBP1) has key functions in nucleolar localization and polyphosphoinositide interaction. Biochem J 2016, 473, (14), 2033-47.

30. Gavgani, F. M.; Arnesen, V. S.; Jacobsen, R. G.; Krakstad, C.; Hoivik, E. A.; Lewis, A. E., Class I Phosphoinositide 3-Kinase PIK3CA/p110 alpha and PIK3CB/p110 beta Isoforms in Endometrial Cancer. Int J Mol Sci 2018, 19, (12).

31. O'Hara, A. J.; Bell, D. W., The genomics and genetics of endometrial cancer. Adv Genomics Genet 2012, 2012, (2), 33-47.

32. Cheung, L. W.; Hennessy, B. T.; Li, J.; Yu, S.; Myers, A. P.; Djordjevic, B.; Lu, Y.; StemkeHale, K.; Dyer, M. D.; Zhang, F.; Ju, Z.; Cantley, L. C.; Scherer, S. E.; Liang, H.; Lu, K. H.; Broaddus, R. R.; Mills, G. B., High frequency of PIK3R1 and PIK3R2 mutations in endometrial cancer elucidates a novel mechanism for regulation of PTEN protein stability. Cancer discovery 2011, 1, (2), 170-85.

33. Mutter, G. L.; Lin, M. C.; Fitzgerald, J. T.; Kum, J. B.; Baak, J. P.; Lees, J. A.; Weng, L. P.; Eng, C., Altered PTEN expression as a diagnostic marker for the earliest endometrial precancers. Journal of the National Cancer Institute 2000, 92, (11), 924-30.

34. Hayes, M. P.; Wang, H.; Espinal-Witter, R.; Douglas, W.; Solomon, G. J.; Baker, S. J.; Ellenson, L. H., PIK3CA and PTEN mutations in uterine endometrioid carcinoma and complex atypical hyperplasia. Clinical cancer research : an official journal of the American Association for Cancer Research 2006, 12, (20 Pt 1), 5932-5.

35. Oda, K.; Stokoe, D.; Taketani, Y.; McCormick, F., High frequency of coexistent mutations of PIK3CA and PTEN genes in endometrial carcinoma. Cancer Res 2005, 65, (23), 10669-73. 
bioRxiv preprint doi: https://doi.org/10.1101/2019.12.20.884122; this version posted December 20, 2019. The copyright holder for this preprint (which was not certified by peer review) is the author/funder. All rights reserved. No reuse allowed without permission.

36. $\quad$ Rudd, M. L.; Price, J. C.; Fogoros, S.; Godwin, A. K.; Sgroi, D. C.; Merino, M. J.; Bell, D. W., A unique spectrum of somatic PIK3CA (p110alpha) mutations within primary endometrial carcinomas. Clinical cancer research : an official journal of the American Association for Cancer Research 2011, 17, (6), 1331-40.

37. Kuhn, E.; Wu, R. C.; Guan, B.; Wu, G.; Zhang, J. H.; Wang, Y.; Song, L.; Yuan, X. G.; Wei, L.; Roden, R. B. S.; Kuo, K. T.; Nakayama, K.; Clarke, B.; Shaw, P.; Olvera, N.; Kurman, R. J.; Levine, D. A.; Wang, T. L.; Shih, I. M., Identification of Molecular Pathway Aberrations in Uterine Serous Carcinoma by Genome-wide Analyses. Jnci-J Natl Cancer I 2012, 104, (19), 1503-1513.

38. Le Gallo, M.; O'Hara, A. J.; Rudd, M. L.; Urick, M. E.; Hansen, N. F.; O'Neil, N. J.; Price, J. C.; Zhang, S.; England, B. M.; Godwin, A. K.; Sgroi, D. C.; Hieter, P.; Mullikin, J. C.; Merino, M. J.; Bell, D. W.; NISC, N. I. S. C., Exome sequencing of serous endometrial tumors identifies recurrent somatic mutations in chromatin-remodeling and ubiquitin ligase complex genes. Nat Genet 2012, 44, (12), 1310-1315.

39. Konopka, B.; Janiec-Jankowska, A.; Kwiatkowska, E.; Najmola, U.; Bidzinski, M.; Olszewski, W.; Goluda, C., PIK3CA mutations and amplification in endometrioid endometrial carcinomas: relation to other genetic defects and clinicopathologic status of the tumors. Hum Pathol 2011, 42, (11), 1710-9.

40. Kandoth, C.; Schultz, N.; Cherniack, A. D.; Akbani, R.; Liu, Y.; Shen, H.; Robertson, A. G.; Pashtan, I.; Shen, R.; Benz, C. C.; Yau, C.; Laird, P. W.; Ding, L.; Zhang, W.; Mills, G. B.; Kucherlapati, R.; Mardis, E. R.; Levine, D. A., Integrated genomic characterization of endometrial carcinoma. Nature 2013, 497, (7447), 67-73.

41. Oda, K.; Okada, J.; Timmerman, L.; Rodriguez-Viciana, P.; Stokoe, D.; Shoji, K.; Taketani, Y.; Kuramoto, H.; Knight, Z. A.; Shokat, K. M.; McCormick, F., PIK3CA cooperates with other phosphatidylinositol 3'-kinase pathway mutations to effect oncogenic transformation. Cancer Res 2008, 68, (19), 8127-36.

42. Urick, M. E.; Rudd, M. L.; Godwin, A. K.; Sgroi, D.; Merino, M.; Bell, D. W., PIK3R1 (p85alpha) is somatically mutated at high frequency in primary endometrial cancer. Cancer Res 2011, 71, (12), 4061-7.

43. Salvesen, H. B.; Carter, S. L.; Mannelqvist, M.; Dutt, A.; Getz, G.; Stefansson, I. M.; Raeder, M. B.; Sos, M. L.; Engelsen, I. B.; Trovik, J.; Wik, E.; Greulich, H.; Bo, T. H.; Jonassen, I.; Thomas, R. K.; Zander, T.; Garraway, L. A.; Oyan, A. M.; Sellers, W. R.; Kalland, K. H.; Meyerson, M.; Akslen, L. A.; Beroukhim, R., Integrated genomic profiling of endometrial carcinoma associates aggressive tumors with indicators of PI3 kinase activation. Proc Natl Acad Sci U S A 2009, 106, (12), 4834-9.

44. $\quad$ Forbes, S. A.; Bindal, N.; Bamford, S.; Cole, C.; Kok, C. Y.; Beare, D.; Jia, M.; Shepherd, R.; Leung, K.; Menzies, A.; Teague, J. W.; Campbell, P. J.; Stratton, M. R.; Futreal, P. A., COSMIC: mining complete cancer genomes in the Catalogue of Somatic Mutations in Cancer. Nucleic Acids Res 2011, 39, (Database issue), D945-50.

45. Kim, E.; Ilic, N.; Shrestha, Y.; Zou, L. H.; Kamburov, A.; Zhu, C.; Yang, X. P.; Lubonja, R.; Tran, N.; Nguyen, C.; Lawrence, M. S.; Piccioni, F.; Bagul, M.; Doench, J. G.; Chouinard, C. R.; Wu, X. Y.; Hogstrom, L.; Natoli, T.; Tamayo, P.; Horn, H.; Corsello, S. M.; Lage, K.; Root, D. E.; Subramanian, A.; Golub, T. R.; Getz, G.; Boehm, J. S.; Hahn, W. C., Systematic Functional Interrogation of Rare Cancer Variants Identifies Oncogenic Alleles. Cancer discovery 2016, 6, (7), 714-726. 
46. $\quad$ An, H. J.; Cho, N. H.; Yang, H. S.; Kwak, K. B.; Kim, N. K.; Oh, D. Y.; Lee, S. W.; Kim, H. O.; Koh, J. J., Targeted RNA interference of phosphatidylinositol 3-kinase p110-beta induces apoptosis and proliferation arrest in endometrial carcinoma cells. $J$ Pathol 2007, 212, (2), 1619.

47. Karlsson, T.; Krakstad, C.; Tangen, I. L.; Hoivik, E. A.; Pollock, P. M.; Salvesen, H. B.; Lewis, A. E., Endometrial cancer cells exhibit high expression of p110beta and its selective inhibition induces variable responses on PI3K signaling, cell survival and proliferation. Oncotarget 2017, 8, (3), 3881-3894.

48. Guillou, H.; Lecureuil, C.; Anderson, K. E.; Suire, S.; Ferguson, G. J.; Ellson, C. D.; Gray, A.; Divecha, N.; Hawkins, P. T.; Stephens, L. R., Use of the GRP1 PH domain as a tool to measure the relative levels of PtdIns(3,4,5)P3 through a protein-lipid overlay approach. $J$ Lipid Res 2007, 48, (3), 726-32.

49. Martin, C.; Chen, S.; Maya-Mendoza, A.; Lovric, J.; Sims, P. F.; Jackson, D. A., Lamin B1 maintains the functional plasticity of nucleoli. J Cell Sci 2009, 122, (Pt 10), 1551-62.

50. Boisvert, F. M.; van Koningsbruggen, S.; Navascues, J.; Lamond, A. I., The multifunctional nucleolus. Nat Rev Mol Cell Biol 2007, 8, (7), 574-85.

51. Grummt, I., Life on a planet of its own: regulation of RNA polymerase I transcription in the nucleolus. Genes Dev 2003, 17, (14), 1691-702.

52. Montanaro, L.; Trere, D.; Derenzini, M., Changes in ribosome biogenesis may induce cancer by down-regulating the cell tumor suppressor potential. Biochim Biophys Acta 2012, 1825, (1), 101-10.

53. Perez-Garcia, V.; Redondo-Munoz, J.; Kumar, A.; Carrera, A. C., Cell activation-induced phosphoinositide 3-kinase alpha/beta dimerization regulates PTEN activity. Mol Cell Biol 2014.

54. Maag, D.; Maxwell, M. J.; Hardesty, D. A.; Boucher, K. L.; Choudhari, N.; Hanno, A. G.; Ma, J. F.; Snowman, A. S.; Pietropaoli, J. W.; Xu, R.; Storm, P. B.; Saiardi, A.; Snyder, S. H.; Resnick, A. C., Inositol polyphosphate multikinase is a physiologic PI3-kinase that activates Akt/PKB. Proc Natl Acad Sci U S A 2011, 108, (4), 1391-6.

55. Resnick, A. C.; Snowman, A. M.; Kang, B. N.; Hurt, K. J.; Snyder, S. H.; Saiardi, A., Inositol polyphosphate multikinase is a nuclear PI3-kinase with transcriptional regulatory activity. Proc Natl Acad Sci U S A 2005, 102, (36), 12783-8.

56. Lim, M. A.; Kikani, C. K.; Wick, M. J.; Dong, L. Q., Nuclear translocation of 3'phosphoinositide-dependent protein kinase 1 (PDK-1): a potential regulatory mechanism for PDK-1 function. Proc Natl Acad Sci U S A 2003, 100, (24), 14006-11.

57. Rosner, M.; Hengstschlager, M., Cytoplasmic and nuclear distribution of the protein complexes mTORC1 and mTORC2: rapamycin triggers dephosphorylation and delocalization of the mTORC2 components rictor and sin1. Hum Mol Genet 2008, 17, (19), 2934-48.

58. Scheid, M. P.; Parsons, M.; Woodgett, J. R., Phosphoinositide-dependent phosphorylation of PDK1 regulates nuclear translocation. Mol Cell Biol 2005, 25, (6), 2347-63.

59. Sephton, C. F.; Zhang, D.; Lehmann, T. M.; Pennington, P. R.; Scheid, M. P.; Mousseau, D. D., The nuclear localization of 3'-phosphoinositide-dependent kinase-1 is dependent on its association with the protein tyrosine phosphatase SHP-1. Cell Signal 2009, 21, (11), 1634-44. 
60. Hannan, K. M.; Brandenburger, Y.; Jenkins, A.; Sharkey, K.; Cavanaugh, A.; Rothblum, L.; Moss, T.; Poortinga, G.; McArthur, G. A.; Pearson, R. B.; Hannan, R. D., mTOR-dependent regulation of ribosomal gene transcription requires S6K1 and is mediated by phosphorylation of the carboxy-terminal activation domain of the nucleolar transcription factor UBF. Mol Cell Biol 2003, 23, (23), 8862-77.

61. James, M. J.; Zomerdijk, J. C., Phosphatidylinositol 3-kinase and mTOR signaling pathways regulate RNA polymerase I transcription in response to IGF-1 and nutrients. J Biol Chem 2004, 279, (10), 8911-8.

62. Iadevaia, V.; Zhang, Z.; Jan, E.; Proud, C. G., mTOR signaling regulates the processing of prerRNA in human cells. Nucleic Acids Res 2012, 40, (6), 2527-39.

63. Ahn, J. Y.; Liu, X.; Cheng, D.; Peng, J.; Chan, P. K.; Wade, P. A.; Ye, K., Nucleophosmin/B23, a nuclear $\mathrm{PI}(3,4,5) \mathrm{P}(3)$ receptor, mediates the antiapoptotic actions of NGF by inhibiting CAD. Mol Cell 2005, 18, (4), 435-45.

64. Hamilton, G.; Abraham, A. G.; Morton, J.; Sampson, O.; Pefani, D. E.; Khoronenkova, S.; Grawenda, A.; Papaspyropoulos, A.; Jamieson, N.; McKay, C.; Sansom, O.; Dianov, G. L.; O'Neill, E., AKT regulates NPM dependent ARF localization and p53(mut) stability in tumors. Oncotarget 2014, 5, (15), 6142-6167.

65. Lee, S. B.; Xuan Nguyen, T. L.; Choi, J. W.; Lee, K. H.; Cho, S. W.; Liu, Z.; Ye, K.; Bae, S. S.; Ahn, J. Y., Nuclear Akt interacts with B23/NPM and protects it from proteolytic cleavage, enhancing cell survival. Proc Natl Acad Sci U S A 2008, 105, (43), 16584-9.

66. Lindstrom, M. S., NPM1/B23: A Multifunctional Chaperone in Ribosome Biogenesis and Chromatin Remodeling. Biochem Res Int 2011, 2011, 195209.

67. Nguyen le, X. T.; Mitchell, B. S., Akt activation enhances ribosomal RNA synthesis through casein kinase II and TIF-IA. Proc Natl Acad Sci U S A 2013, 110, (51), 20681-6.

68. Traynor-Kaplan, A.; Kruse, M.; Dickson, E. J.; Dai, G.; Vivas, O.; Yu, H.; Whittington, D.; Hille, B., Fatty-acyl chain profiles of cellular phosphoinositides. Biochim Biophys Acta 2017, 1862, (5), 513-522.

69. Anderson, K. E.; Juvin, V.; Clark, J.; Stephens, L. R.; Hawkins, P. T., Investigating the effect of arachidonate supplementation on the phosphoinositide content of MCF10a breast epithelial cells. Advances in Biological Regulation 2016, 62, 18-24.

70. $\quad$ Clark, J.; Anderson, K. E.; Juvin, V.; Smith, T. S.; Karpe, F.; Wakelam, M. J.; Stephens, L. R.; Hawkins, P. T., Quantification of PtdInsP3 molecular species in cells and tissues by mass spectrometry. Nat Methods 2011, 8, (3), 267-72.

71. Kyo, S.; Nakamura, M.; Kiyono, T.; Maida, Y.; Kanaya, T.; Tanaka, M.; Yatabe, N.; Inoue, M., Successful immortalization of endometrial glandular cells with normal structural and functional characteristics. The American journal of pathology 2003, 163, (6), 2259-69.

72. Mizumoto, Y.; Kyo, S.; Ohno, S.; Hashimoto, M.; Nakamura, M.; Maida, Y.; Sakaguchi, J.; Takakura, M.; Inoue, M.; Kiyono, T., Creation of tumorigenic human endometrial epithelial cells with intact chromosomes by introducing defined genetic elements. Oncogene 2006, 25, (41), 5673-82.

73. O'Carroll, S. J.; Mitchell, M. D.; Faenza, I.; Cocco, L.; Gilmour, R. S., Nuclear PLCbeta1 is required for 3T3-L1 adipocyte differentiation and regulates expression of the cyclin D3-cdk4 complex. Cell Signal 2009, 21, (6), 926-35. 
bioRxiv preprint doi: https://doi.org/10.1101/2019.12.20.884122; this version posted December 20, 2019. The copyright holder for this preprint (which was not certified by peer review) is the author/funder. All rights reserved. No reuse allowed without permission.

74. Lam, Y.; I. Lamond, A., Isolation of Nucleoli. 2006; Vol. 2, p 103-107.

75. Popov, A.; Smirnov, E.; Kovacik, L.; Raska, O.; Hagen, G.; Stixova, L.; Raska, I., Duration of the first steps of the human rRNA processing. Nucleus 2013, 4, (2), 134-41.

76. Gabriel, J. M.; Higgins, M. J.; Gebuhr, T. C.; Shows, T. B.; Saitoh, S.; Nicholls, R. D., A model system to study genomic imprinting of human genes. Proceedings of the National Academy of Sciences of the United States of America 1998, 95, (25), 14857-14862.

77. Gray, A.; Olsson, H.; Batty, I. H.; Priganica, L.; Peter Downes, C., Nonradioactive methods for the assay of phosphoinositide 3-kinases and phosphoinositide phosphatases and selective detection of signaling lipids in cell and tissue extracts. Anal Biochem 2003, 313, (2), 234-45.

78. Lewis, A. E.; Sommer, L.; Arntzen, M. O.; Strahm, Y.; Morrice, N. A.; Divecha, N.; D'Santos, C. S., Identification of nuclear phosphatidylinositol 4,5-bisphosphate-interacting proteins by neomycin extraction. Mol Cell Proteomics 2011, 10, (2), M110 003376.

79. Berg, A.; Hoivik, E. A.; Mjos, S.; Holst, F.; Werner, H. M.; Tangen, I. L.; Taylor-Weiner, A.; Gibson, W. J.; Kusonmano, K.; Wik, E.; Trovik, J.; Halle, M. K.; Oyan, A. M.; Kalland, K. H.; Cherniack, A. D.; Beroukhim, R.; Stefansson, I.; Mills, G. B.; Krakstad, C.; Salvesen, H. B., Molecular profiling of endometrial carcinoma precursor, primary and metastatic lesions suggests different targets for treatment in obese compared to non-obese patients. Oncotarget 2015, 6, (2), 1327-39.

80. Tangen, I. L.; Werner, H. M. J.; Berg, A.; Halle, M. K.; Kusonmano, K.; Trovik, J.; Hoivik, E. A.; Mills, G. B.; Krakstad, C.; Salvesen, H. B., Loss of progesterone receptor links to high proliferation and increases from primary to metastatic endometrial cancer lesions. Eur J Cancer 2014, 50, (17), 3003-3010. 